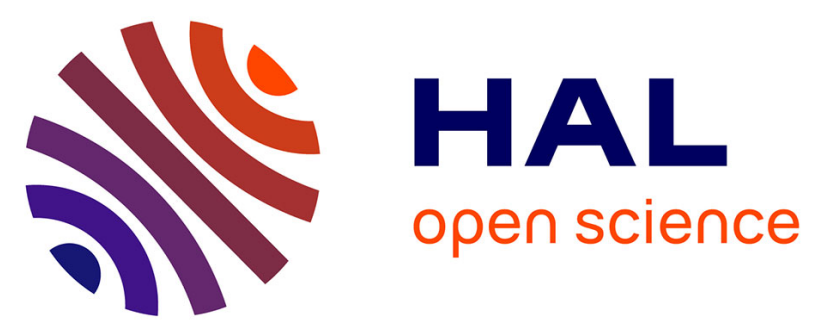

\title{
Quantifying Nitrous Acid Formation Mechanisms Using Measured Vertical Profiles During the CalNex 2010 Campaign and 1D Column Modeling
}

Katie Tuite, Jennie L Thomas, Patrick Veres, James Roberts, Philip Stevens, Stephen Griffith, Sebastien Dusanter, James Flynn, Shaddy Ahmed, Louisa Emmons, et al.

\section{To cite this version:}

Katie Tuite, Jennie L Thomas, Patrick Veres, James Roberts, Philip Stevens, et al.. Quantifying Nitrous Acid Formation Mechanisms Using Measured Vertical Profiles During the CalNex 2010 Campaign and 1D Column Modeling. Journal of Geophysical Research: Atmospheres, 2021, 126 (13), pp.e2021JD034689. 10.1029/2021JD034689 . hal-03357646

\section{HAL Id: hal-03357646 https://hal.science/hal-03357646}

Submitted on 19 Oct 2021

HAL is a multi-disciplinary open access archive for the deposit and dissemination of scientific research documents, whether they are published or not. The documents may come from teaching and research institutions in France or abroad, or from public or private research centers.
L'archive ouverte pluridisciplinaire HAL, est destinée au dépôt et à la diffusion de documents scientifiques de niveau recherche, publiés ou non, émanant des établissements d'enseignement et de recherche français ou étrangers, des laboratoires publics ou privés. 


\section{Quantifying nitrous acid formation mechanisms using measured vertical profiles during the CalNex 2010 campaign and 1D column modeling}

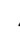

\section{Katie Tuite ${ }^{1}$, Jennie L. Thomas ${ }^{2}$, Patrick R. Veres ${ }^{3}$, James M. Roberts ${ }^{3}$,} Philip S. Stevens ${ }^{4}$, Stephen M. Griffith ${ }^{8}$, Sebastien Dusanter ${ }^{9}$, James H. Flynn $^{5}$, Shaddy Ahmed ${ }^{2}$, Louisa Emmons ${ }^{6}$, Si-Wan Kim ${ }^{7}$, Rebecca Washenfelder $^{3}$, Cora Young ${ }^{10}$, Catalina Tsai ${ }^{11}$, Olga Pikelnaya ${ }^{11}$, Jochen Stutz ${ }^{1}$

${ }^{1}$ Department of Atmospheric and Oceanic Sciences, University of California Los Angeles, Los Angeles, CA, USA

${ }^{2}$ Institut des Géosciences de l'Environnement, Univ Grenoble Alpes, CNRS, IRD, Grenoble INP, Grenoble, France

${ }^{3}$ Earth Systems Research Laboratory, National Oceanic and Atmospheric Administration, Boulder, CO, USA

${ }^{4}$ School of Public and Environmental Affairs and Department of Chemistry, Indiana University, Bloomington, IN, USA

${ }^{5}$ Department of Earth and Atmospheric Sciences, University of Houston, Houston, TX, USA

${ }^{6}$ Atmospheric Chemistry Observations and Modeling Lab, National Center for Atmospheric Research,

$$
\text { Boulder, CO, USA }
$$

${ }^{7}$ Department of Atmospheric Sciences, Yonsei University, Seoul, Korea

${ }^{8}$ Department of Atmospheric Sciences, National Central University, Taoyuan, Taiwan

${ }^{9}$ Département Sciences de l'Atmosphére et Génie de l'Environnement, IMT Lille Douai, Univ Lille, Lille, France

${ }^{10}$ Department of Chemistry, York University, Ontario, Canada

${ }^{11}$ South Coast Air Quality Management District, Diamond Bar, CA USA

Corresponding author: Jochen Stutz, jochen@atmos.ucla.edu

Corresponding author: Jennie Thomas, jennie.thomas@univ-grenoble-alpes.fr 
- A new 1D chemistry and transport model that includes HONO formation on the ground reproduces the HONO concentration profiles.

- The main daytime HONO source is adsorbed nitric acid/ nitrate photolysis, followed by photo-enhanced $\mathrm{NO}_{2}$ conversion. 


\section{Abstract}

Nitrous acid (HONO) is an important radical precursor that can impact secondary pollutant levels, especially in urban environments. Due to uncertainties in its heterogeneous formation mechanisms, models often under predict HONO concentrations. A number of heterogeneous sources at the ground have been proposed but there is no consensus about which play a significant role in the urban boundary layer. We present a new one-dimensional chemistry and transport model which performs surface chemistry based on molecular collisions and chemical conversion, allowing us to add detailed HONO formation chemistry at the ground. We conducted model runs for the 2010 CalNex campaign, finding good agreement with observations for key species such as $\mathrm{O}_{3}, \mathrm{NO}_{x}$, and $\mathrm{HO}_{x}$. With the ground sources implemented, the model captures the diurnal and vertical profile of the HONO observations. Primary $\mathrm{HO}_{x}$ production from $\mathrm{HONO}$ photolysis is 2-3 times more important than $\mathrm{O}_{3}$ or $\mathrm{HCHO}$ photolysis at mid-day, below $10 \mathrm{~m}$. The HONO concentration, and its contribution to $\mathrm{HO}_{x}$, decreases quickly with altitude. Heterogeneous chemistry at the ground provided a HONO source of $2.5 \times 10^{11}$ molecules $\mathrm{cm}^{-2} \mathrm{~s}^{-1}$ during the day and $5 \times 10^{10}$ molecules $\mathrm{cm}^{-2} \mathrm{~s}^{-1}$ at night. The night time source was dominated by $\mathrm{NO}_{2}$ hydrolysis. During the day, photolysis of surface $\mathrm{HNO}_{3} /$ nitrate contributed $45-60 \%$ and photo-enhanced conversion of $\mathrm{NO}_{2}$ contributed $20-45 \%$. Sensitivity studies addressing the uncertainties in both photolytic mechanisms show that, while the relative contribution of either source can vary, $\mathrm{HNO}_{3} /$ nitrate is required to produce a surface HONO source that is strong enough to explain observations.

\section{Introduction}

Nitrous acid (HONO) chemistry in the polluted boundary layer has been an area of research for nearly five decades. It is well established that HONO photolysis (R1) is an important source of hydroxyl radicals $(\mathrm{OH})$ throughout the day, contributing up to $55 \%$ of the primary OH formation (Alicke et al., 2002, 2003; Kleffmann et al., 2005; Kleffmann, 2007; Ren et al., 2003; Volkamer et al., 2010; Young et al., 2012; Elshorbany et al., 2009; Mao et al., 2010; Dusanter et al., 2009). 
Although it has a large impact on the oxidative capacity of the atmosphere, HONO chemistry is often excluded from or simplified in 3D air quality models due to uncertainties in its formation mechanisms. This leads to an underestimation of HONO, which consequently impacts predicted concentrations of radicals and secondary pollutants like ozone (Czader et al., 2012; Elshorbany et al., 2012). Developing accurate HONO source representation is necessary to improve air quality modeling, which is increasingly important as air quality standards become more strict (Sarwar et al., 2008).

HONO chemistry includes homogeneous and heterogeneous reactions, biological processes in soil, and direct emission from combustion sources (Figure 1). The main gas phase reactions include loss via photolysis $(\mathrm{R} 1)$ and reaction with $\mathrm{OH}(\mathrm{R} 2)$, and production through the $\mathrm{NO}+\mathrm{OH}$ reaction $(\mathrm{R} 3)$.
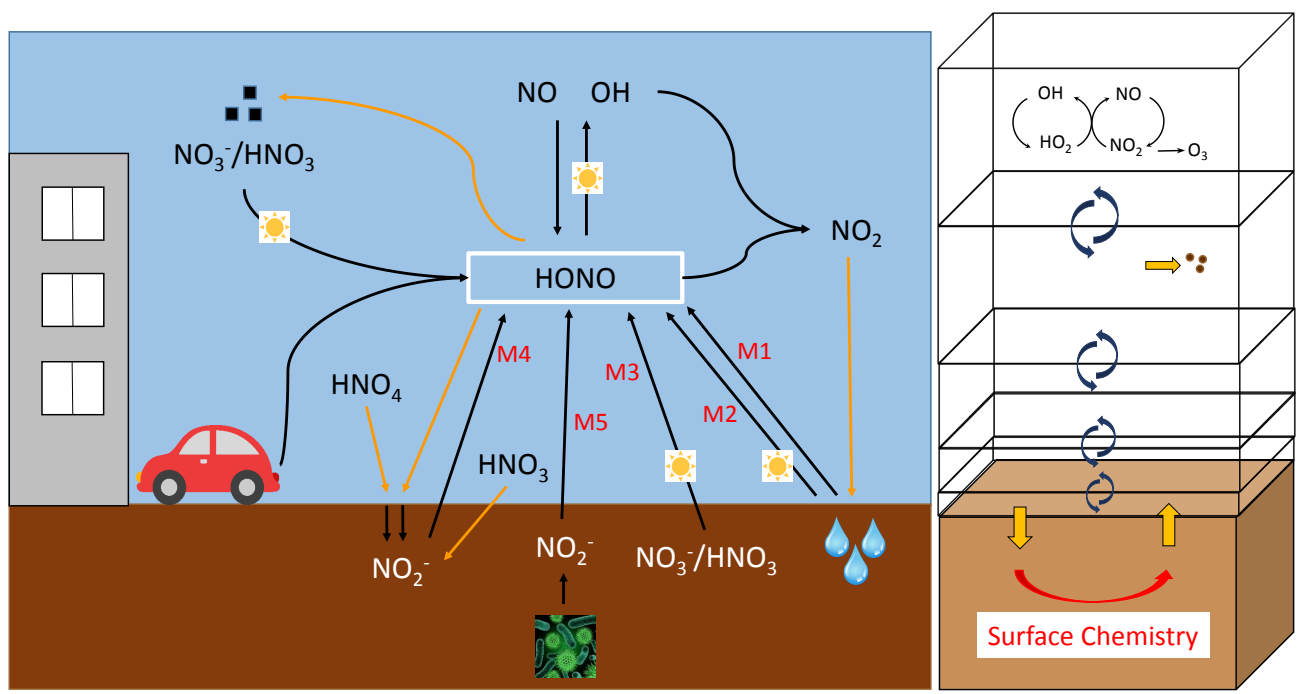

Figure 1. The cartoon on the left shows common HONO sources and sinks, with heterogeneous processes labeled M1-M5 in red. On the right is an example model grid schematic showing the interaction between gas phase chemistry, surface chemistry, vertical mixing, and aerosol uptake.

$$
\mathrm{OH}+\mathrm{NO} \stackrel{\mathrm{M}}{\longrightarrow} \mathrm{HONO}
$$


Measured diurnal profiles show that HONO concentrations accumulate throughout the night and drop off in the early morning once photolysis becomes active. Nocturnal surface levels can reach up to several ppb in urban regions (Kleffmann et al., 2006; Stutz et al., 2010; Wong et al., 2011), while daytime levels have been reported up to a few hundred ppt (Kleffmann et al., 2005; Acker et al., 2006; Zhou et al., 2007; Wong et al., 2012). A strong HONO source is required to maintain these levels, particularly during the day when the HONO lifetime is only 10-20 minutes.

Pseudo-steady state (PSS) calculations and models show that HONO levels are greatly underestimated when only homogeneous chemistry (R1 - R3) is considered (Zhou et al., 2002; Kleffmann et al., 2005; Kleffmann, 2007; Tsai et al., 2018; Sarwar et al., 2008; Li et al., 2011; Czader et al., 2012). HONO is directly emitted by anthropogenic combustion processes, but this is less than $1 \%$ of $\mathrm{NO}_{x}$ emissions (Kirchstetter et al., 1996; Kurtenbach et al., 2001; Neuman et al., 2016; Kramer et al., 2019) and cannot explain atmospheric levels by itself. Measured vertical profiles show HONO concentrations are greatest near the ground (Kleffmann et al., 2003; Villena et al., 2011; Wong et al., 2011, 2012; VandenBoer et al., 2013), indicating that a surface source is likely. Multiple heterogeneous formation mechanisms have therefore been proposed to explain this missing HONO source.

\subsection{Heterogeneous HONO chemistry}

Laboratory studies have found that $\mathrm{HONO}$ is produced from $\mathrm{NO}_{2}$ conversion on humid surfaces (mechanism M1 in Figure 1), following a reaction mechanism (R4) which is first order with respect to both $\mathrm{NO}_{2}$ and water vapor (Sakamaki et al., 1983; Svensson et al., 1987; Pitts et al., 1984; Jenkin et al., 1988; Lammel \& Cape, 1996).

$$
2 \mathrm{NO}_{2}+\mathrm{H}_{2} \mathrm{O} \stackrel{\text { surface }}{\longrightarrow} \mathrm{HONO}+\mathrm{HNO}_{3}
$$

There is significant evidence that this reaction is the main source of nocturnal HONO and allows for an accurate description of $\mathrm{HONO}$ and $\mathrm{HONO} / \mathrm{NO}_{2}$ ratios at night (Alicke et al., 2003; Kleffmann et al., 2003; Wong et al., 2011; VandenBoer et al., 2013). While R4 occurs during the day as well, it does not produce HONO at the rate needed to sustain daytime levels and many studies have shown evidence that a photolytic source is required (Alicke et al., 2002; Kleffmann et al., 2005; Acker et al., 2006; Wong et al., 2012). 
Photo-enhanced heterogeneous conversion of $\mathrm{NO}_{2}$ to HONO (M2 in Figure 1) has been found to occur on a variety of surfaces, including soot (Ammann et al., 1998; Aubin \& Abbatt, 2007; Khalizov et al., 2010; Monge et al., 2010), humic acid (Stemmler et al., 2006, 2007; Bartels-Rausch et al., 2010), and organic films (Gutzwiller et al., 2002; George et al., 2005; Brigante et al., 2008). A mechanism proposed by Stemmler et al. (2006) suggests $\mathrm{HONO}$ formation from $\mathrm{NO}_{2}$ conversion on humic acid surfaces is first order in $\mathrm{NO}_{2}$ and linearly dependent on irradiance and surface area (SA).

$$
P_{\mathrm{HONO}} \propto \mathrm{SA} \times\left[\mathrm{NO}_{2}\right] \times \text { irradiance }
$$

Wong et al. (2013) included a sunlight dependent $\mathrm{NO}_{2}$ to $\mathrm{HONO}$ reactive uptake coefficient $(\gamma)$ in their 1D model study and found good agreement between modeled and observed HONO levels during the 2009 SHARP field campaign in Texas. Without this parameterization, daytime HONO levels were underestimated by at least $50 \%$. Other studies also suggest this conversion provides a major daytime source, showing that HONO correlates with $\mathrm{NO}_{2}$ levels and/or $\mathrm{NO}_{2}$ photolysis rates (Vogel et al., 2003; Laufs et al., 2017; Tsai et al., 2018).

Another daytime $\mathrm{HONO}$ source is the photolysis of surface adsorbed $\mathrm{HNO}_{3} /$ nitrate (M3 in Figure 1), which proceeds at a rate 1-4 orders of magnitude faster than gas phase or aqueous $\mathrm{HNO}_{3}$ photolysis (Zhou et al., 2002, 2003; Ramazan et al., 2004; Baergen \& Donaldson, 2013, 2016; Ye et al., 2016, 2019). R5 - R8 describes the mechanism proposed by Zhou et al. (2002). $\mathrm{NO}_{2}$ in $\mathrm{R} 7$ is the dominant product over $\mathrm{R} 6$ in the actinic region of solar radiation.

$$
\begin{gathered}
\mathrm{HNO}_{3(\mathrm{ads})}+h \nu \rightarrow\left[\mathrm{HNO}_{3}\right]^{*}{ }_{(\mathrm{ads})} \\
{\left[\mathrm{HNO}_{3}\right]^{*}{ }_{(\mathrm{ads})} \rightarrow \mathrm{HONO}_{(\mathrm{ads})}+\mathrm{O}\left({ }^{3} \mathrm{P}\right)_{(\mathrm{ads})}} \\
{\left[\mathrm{HNO}_{3}\right]^{*}{ }_{(\text {ads })} \rightarrow \mathrm{NO}_{2(\mathrm{ads})}+\mathrm{OH}} \\
2 \mathrm{NO}_{2(\text { ads })}+\mathrm{H}_{2} \mathrm{O}_{(\text {ads })} \rightarrow \mathrm{HONO}_{(\text {ads })}+\mathrm{HNO}_{3(\text { ads })}
\end{gathered}
$$

The HONO produced in R6 and R8 can desorb from the surface into the gas phase. This mechanism has been shown to be important in low $\mathrm{NO}_{x}$ forested environments (Zhou et al., 2011; Zhang et al., 2012). Although photo-enhanced conversion of $\mathrm{NO}_{2}$ is often 
thought to be the dominant $\mathrm{HONO}$ formation pathway in high $\mathrm{NO}_{x}$ areas, $\mathrm{HNO}_{3}$ photolysis has also been confirmed as a significant source in the urban regions near Philadelphia (Sarwar et al., 2008) and Houston (Karamchandani et al., 2014). Enhanced photolysis has been shown to occur on glass (Zhou et al., 2002; Ye et al., 2019), building materials (Ye et al., 2016), and urban grime (Baergen \& Donaldson, 2013, 2016), indicating that this mechanism likely plays a role in urban HONO production.

Both of these proposed photolytic mechanisms can occur on aerosols in addition to the ground. Due to the much smaller surface area available on aerosols and deactivation of reactive sites during aging, the aerosol source is thought to be minor in comparison in typical settings (Kalberer et al., 1999; Kleffmann et al., 2003; Vogel et al., 2003; Stemmler et al., 2007).

A recent HONO source proposed by VandenBoer et al. (2015) is the displacement of surface nitrite by strong atmospheric acids like $\mathrm{HCl}$ and $\mathrm{HNO}_{3}$ (M4 in Figure 1). Throughout the night, the primary HONO sink is deposition to the surface, where it can react with carbonate material to form nitrite.

$$
\mathrm{MCO}_{3(\mathrm{~s})}+2 \mathrm{HONO}_{(\mathrm{g})} \rightarrow \mathrm{MNO}_{2}+\mathrm{CO}_{2}+\mathrm{H}_{2} \mathrm{O}
$$

VandenBoer et al. (2013) suggests that this nocturnally deposited HONO may form a surface reservoir that can be released the following day. Laboratory studies find that $\mathrm{HCl}$ and $\mathrm{HNO}_{3}$ can displace surface nitrite with an efficiency of 1-20\%. Using the mean value of $9 \%$, VandenBoer et al. (2015) showed that this mechanism contributed up to $23 \%$ of the total noontime HONO flux in Bakersfield, California during the CalNex campaign.

Biological processes in soil provide another potential atmospheric HONO source (M5 in Figure 1) (Su et al., 2011; Oswald et al., 2013; Maljanen et al., 2013; Scharko et al., 2015; Meusel et al., 2018). Nitrification and denitrification produce nitrite, which undergoes acid-base reactions and partitioning between air and the aqueous phase in soil.

$$
\mathrm{NO}_{2}{ }^{-}{ }_{(\mathrm{aq})}+\mathrm{H}^{+}{ }_{(\mathrm{aq})} \rightarrow \mathrm{HONO}_{(\mathrm{aq})} \rightarrow \mathrm{HONO}_{(\mathrm{g})}
$$

R10 depends on the $\mathrm{pH}$ and $\mathrm{NO}_{2}{ }^{-}$concentration of the soil. Oswald et al. (2013) performed laboratory studies to compare emissions of HONO and NO from soils from a variety of ecosystems. They found that HONO can account for up to $50 \%$ of the total re- 
active nitrogen released from soil, especially in arid and arable soils with water content below $20 \%$ water holding capacity.

\subsection{Linking surface chemistry to atmospheric measurements}

A challenge in studying the link between chemical transformations on the ground and the chemistry in the overlying atmosphere is the role of vertical transport to and from the surface. This was illustrated by 1D modeling studies by Geyer and Stutz (2004a, 2004b), who showed that concentrations change on the scale of one meter or less near the surface. Similar conclusions were derived by nighttime and daytime HONO modeling studies (Wong et al., 2011, 2013; Tsai et al., 2018), which all showed a strong concentration gradient near the surface. Another challenge for modeling studies of atmospheric HONO is the poorly known surface (ground) formation chemistry. To address this issue, flexibility in the model setup and the ability to perform sensitivity studies are essential.

One-dimensional chemistry and transport models are an ideal tool to study poorly constrained surface chemistry. A number of 1D models have provided valuable insight into similar atmospheric systems, such as the interaction of snow with the atmosphere (Cao et al., 2014, 2016; Thomas et al., 2011, 2012; Toyota et al., 2014; Wang et al., 2020), forest canopies (Boy et al., 2011), and the marine boundary layer (von Glasow et al., 2002a, 2002b). However, only few studies have addressed the surface chemistry of HONO (Wong et al., 2011, 2013; Karamchandani et al., 2014; Tsai et al., 2018). To investigate this specific surface-atmosphere chemical system, we present a newly developed 1D model, the Platform for Atmospheric Chemistry and vertical Transport in one dimension (PACT1D). PACT-1D is based on the success of our previous modeling (Wong et al., 2011, 2013; Tsai et al., 2018), and includes improved capability to perform mechanistic and sensitivity studies of these systems.

In this paper we analyze observed vertical concentration profiles of $\mathrm{HONO}, \mathrm{NO}_{2}$, and other compounds during the 2010 CalNex field experiment (Section 2) using PACT1D (Section 3). We use PACT-1D to test if HONO surface formation can reproduce the observations, and explore the contribution of the mechanisms (Section 4). 


\section{Measurements}

The 2010 CalNex experiment took place in Pasadena, CA from mid-May to midJune, 2010 (Ryerson et al., 2013). The ground-site was located on the California Institute of Technology (Caltech) campus with in-situ measurements collected near the surface at altitudes between 3 and $10 \mathrm{~m}$ and remote sensing observations on top of Caltech's library at $\sim 35 \mathrm{~m}$ agl. All CalNex observations are publicly available at www.esrl.noaa.gov/csd/projects/calnex/.

In this study we focus on observations relevant for understanding the formation of HONO and its impact on atmospheric chemistry. We use HONO data from two instruments: UCLA's long-path Differential Optical Absorption Spectroscopy instrument (LPDOAS) and NOAA's Chemical Mass Spectrometer (CIMS). NOAA's CIMS sampled air at $3 \mathrm{~m}$ agl, while the LP-DOAS probed air between $33-556 \mathrm{~m}$ agl in four different altitude intervals. All other in-situ measurements used here were sampled at $10 \mathrm{~m}$ agl on top of a scaffolding tower.

We concentrate on a four day period, May 26 - May 30, 2010, during which a variety of conditions were encountered, including cloudy days and the highest ozone levels of the experiment. This period also has the best coverage of all instruments, in particular the LP-DOAS instrument.

\subsection{LP-DOAS}

The setup of the LP-DOAS during CalNex, as well as the data retrieval techniques, have been described previously (Wong et al., 2011, 2012; Tsai et al., 2014), therefore we will only briefly describe them here. Figure 2 shows a schematic of the site setup. The LP-DOAS consists of a main telescope/spectrometer unit, which was located on top of Millikan Library on the Caltech campus at $33 \mathrm{~m}$ altitude. Four arrays of retroreflectors were mounted on a nearby mountain at different distances and altitudes. We refer to these retroreflectors and the associated air samples by their relative altitudes: lower $(78 \mathrm{~m})$, middle $(121 \mathrm{~m})$, high $(255 \mathrm{~m})$, highest $(556 \mathrm{~m})$. The instrument was aimed at the four reflectors using a cycle of measurements with a repeat interval of 15 - 30 min, depending on visibility. The light received back was measured in the 300-380 nm range with a spectral resolution of $0.6 \mathrm{~nm}$. Trace gas path-averaged concentrations were retrieved using established DOAS techniques as described in Platt and Stutz (2008). Average de- 

paths.

tection limits for $\mathrm{NO}_{2}$ and $\mathrm{HONO}$ on a single absorption path were $0.16 \mathrm{ppb}$ and 0.06 ppb, respectively. It should also be pointed out that the LP-DOAS, which was located around $550 \mathrm{~m}$ southeast of the other instruments, averaged over $\sim 5-7 \mathrm{~km}$ absorption light

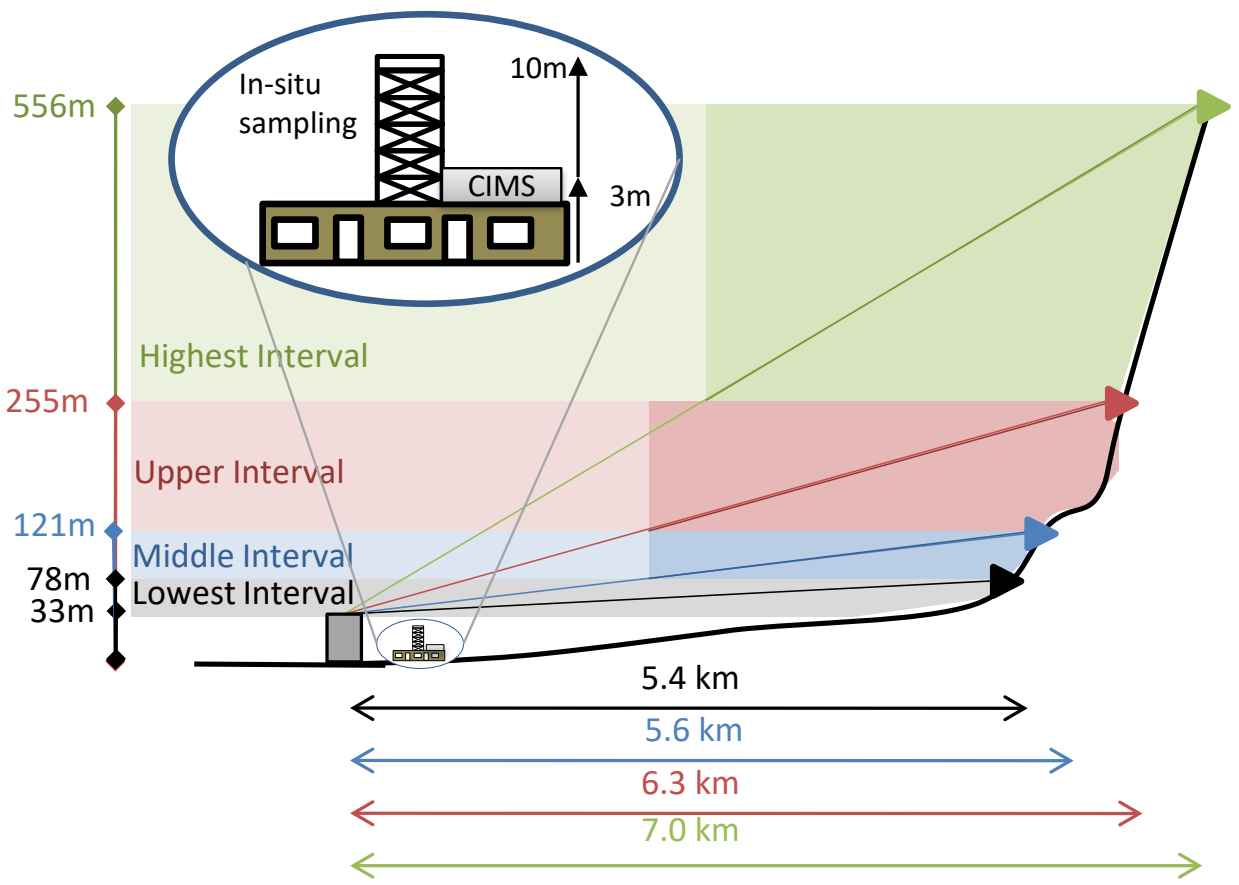

Figure 2. Sketch of the LP-DOAS field setup during the CalNex 2010 experiment

The LP-DOAS measured continuously throughout CalNex, however, low visibility and low clouds blocked the light beams at some times. Low clouds were especially common during the night and often only the lowest light path data was available. The dates chosen for this modeling study had good coverage along all light paths. Vertical profiles from LP-DOAS measurements were constructed following the method described in Tsai et al. (2014). Briefly, the path-averaged mixing ratios were first linearly interpolated onto the time grid of the lowest light path and then converted to height intervalaverage mixing ratios. These averages are reported at the midpoint of each height interval $(55.5,99.5,188$, and $405.5 \mathrm{~m})$. 


\subsection{NI-PT-CIMS}

A negative-ion proton-transfer chemical ionization mass spectrometer (NI-PT-CIMS) using acetate ions provided $\mathrm{HONO}$ and $\mathrm{HNO}_{3}$ observations at 1-minute resolution during CalNex and has been described previously (Roberts et al., 2010; Veres et al., 2011). Briefly, ambient air was sampled through a $1.5 \mathrm{~m}$ PTFE inlet heated from a point approximately $3 \mathrm{~m}$ agl. Acidic molecules are ionized via proton abstraction reactions with acetate ions $\left(\mathrm{CH}_{3} \mathrm{COO}^{-}\right)$and detected, as the conjugate anion, using a quadrupole mass spectrometer. Instrument backgrounds using a sodium carbonate denuder were performed every $190 \mathrm{~min}$ for $30 \mathrm{~min}$.

HONO calibrations were performed in-field approximately every two days using using a portable source described elsewhere (Roberts et al., 2010). Measurement of HONO by the NI-PT-CIMS required correction for $\mathrm{NO}_{2}$. Correction factors were determined through laboratory additions of $\mathrm{NO}_{2}$ as a function of relative humidity with $\mathrm{NO}_{2}$ quantified by CRDS. Detection limits for HONO were $10 \mathrm{ppt}$, with an uncertainty of $30 \%+$ $20 \mathrm{ppt}$ for 1-min measurements. Nitric acid calibrations were performed during post-field laboratory work using a permeation source calibrated using UV optical absorption (Neuman et al., 2003). $\mathrm{HNO}_{3}$ was measured with a detection limit of 15 ppt, with a stated uncertainty of $30 \%+30 \mathrm{ppt}$ for 1-min measurements.

\subsection{Other measurements}

We use a number of other observations from CalNex in our analysis and model evaluation. Table 1 lists these parameters, the respective instruments, and literature references of the CalNex results.

\section{The Platform for Atmospheric Chemistry and vertical Transport in one dimension (PACT-1D)}

\subsection{Model description}

In this study we describe and use a new vertical column model, the Platform for Atmospheric Chemistry and vertical Transport in one dimension (PACT-1D). The new model is similar to past vertical column models used to study the interactions between chemical processing and vertical transport processes, where chemistry is calculated online and dynamics and physics are provided as input (Geyer \& Stutz, 2004a). PACT- 
Table 1. Overview of CalNex measurements used in this study

\begin{tabular}{|c|c|c|c|}
\hline $\begin{array}{l}\text { Species / Param- } \\
\text { eter }\end{array}$ & Instrument & Operator & Reference \\
\hline $\mathrm{O}_{3}$ & UV-absorption & $\begin{array}{l}\text { Univ. Houston } \\
(\mathrm{UH})\end{array}$ & \\
\hline $\mathrm{NO} / \mathrm{NO}_{2}$ & $\begin{array}{l}\text { Chemiuminescence } \\
\text { with photolytic } \\
\text { converter }\end{array}$ & $\begin{array}{l}\text { Univ. Houston } \\
\text { (UH) }\end{array}$ & $\begin{array}{l}\text { (Pollack et al., } \\
2010)\end{array}$ \\
\hline $\mathrm{NO}_{2}$ & $\begin{array}{l}\text { Cavity Ring-Down } \\
\text { Spectroscopy } \\
\text { (CRDS) }\end{array}$ & NOAA & $\begin{array}{l}\text { (Washenfelder et } \\
\text { al., 2011) }\end{array}$ \\
\hline $\mathrm{OH} / \mathrm{HO}_{2}$ & $\begin{array}{l}\text { Laser Induced } \\
\text { Fluorescence (LIF- } \\
\text { FAGE) }\end{array}$ & Indiana Univ. & $\begin{array}{l}\text { (Dusanter et al., } \\
\text { 2009; Griffith et al., } \\
2016 \text { ) }\end{array}$ \\
\hline VOC & GC-MS & NOAA & $\begin{array}{l}\text { (Gilman et al., } \\
\text { 2010; Borbon et al., } \\
\text { 2013) }\end{array}$ \\
\hline Actinic Flux & Spectroradiometer & $\begin{array}{l}\text { Univ. Houston } \\
\text { (UH) }\end{array}$ & $\begin{array}{l}\text { (Shetter \& Müller, } \\
\text { 1999) }\end{array}$ \\
\hline $\begin{array}{l}\text { Aerosol Number } \\
\text { Ditribution }\end{array}$ & TSI SMPS & CU Boulder & (Hayes et al., 2013) \\
\hline $\mathrm{HONO}, \mathrm{HNO}_{3}$ & CIMS & NOAA & (Veres et al., 2008) \\
\hline
\end{tabular}

1D solves both 1D transport and chemical kinetics resulting in the time evolution $(t)$ of a chemical species $(i)$ at altitude $(z)$. The continuity equation for the change in concentration $C$ for the 1D chemical system is given by Eqn 2 .

$$
\frac{d C_{(i, t, z)}}{d t}=P_{(i, t, z)}-L_{(i, t, z)}+F_{(i, t, z)}+E_{(i, t, z)}
$$

$P$ and $L$ represent chemical production and loss, $F$ refers to the flux in/out of the box due to vertical mixing, including loss to the ground (deposition), and $E$ is the rate of 
emissions. We treat each process including chemistry, vertical mixing, and emissions as separable using operator splitting.

Emissions are provided as input and are time and height dependent. Chemical production and loss are described using the Regional Atmospheric Chemistry Mechanism version 2 (RACM2) (Goliff et al., 2013), implemented with the Kinetics Pre-Processor (Sandu \& Sander, 2006). Photolysis rates are provided as input. In addition to the RACM2 gas phase chemistry, we include non-reactive uptake of gases to aerosols and heterogeneous surface reactions on aerosols. For heterogeneous chemistry, the aerosol surface area $(S)$ is prescribed in each model level $(z)$ at a given time $(t)$ according to

$$
S_{(z, t)}=4 \pi r_{(z, t)}^{2} N_{(z, t)}
$$

where $r$ and $N$ represent the radius and number concentration of a mono-disperse aerosol that best represents the surface area available for reactions. Aerosol physical properties $(N$ and $r$ ) are given as model input. Therefore, no aerosol physics is calculated online within the model. Irreversible uptake to and heterogenous reactions on aerosols are treated with the rate constant $\left(k_{T}\right)$ given by

$$
k_{T}=\frac{1}{4} \nu S \gamma J
$$

where $\nu$ is the mean molecular speed, $S$ is the aerosol surface area, and $\gamma$ represents the probability of irreversible uptake or interfacial reaction. The flux of molecules to the aerosol surface in the transition regime, $J$, is calculated according to Fuchs and Sutugin (1971). This corrects the rate of diffusion for gas molecules towards an aerosol surface when the particle size is similar to the mean free path in air, the so called transition regime.

Vertical mixing and loss to the the ground are solved together in the vertical mixing term, given as $F_{(i, t, z)}$ in Eqn. 2. We treat vertical mixing and surface loss (i.e. deposition) for each species according to

$$
\frac{\partial}{\partial t} \phi_{(i, t, z)}=\frac{1}{\rho_{(i, t, z)}} \frac{\partial}{\partial z}\left(\rho_{(i, t, z)} K_{D(i, t, z)} \frac{\partial}{\partial z} \phi_{(i, t, z)}\right)+R_{(1, t)}
$$

where $\phi_{i}$ is the species concentration in mixing ratio units, $\rho$ is the air density, and $R$ represents loss to the ground in the lowest model level. $K_{D(i, t, z)}$ is the sum of eddy diffusivity $\left(K_{(t, z)}\right)$ plus molecular diffusion $\left(D_{(i, t, z)}\right)$. To treat vertical mixing and loss to 
the ground, we discretize the model levels below 1 meter using a log scale grid such that the lowest model level is appropriate for treatment of a laminar molecular diffusive layer in direct contact with the Earth's surface. $K_{(t, z)}$ decreases in a log profile towards the surface to a molecular diffusion coefficient in the lowest model level.

A unique feature of the model is that uptake and chemistry on the ground (R) are calculated using molecular collisions on the ground and applying an uptake probability $(\alpha)$ or reactive uptake coefficient $(\gamma)$. We then solve Eqn. 5 numerically using the CrankNicolson method (Brasseur \& Jacob, 2017), which is numerically stable for a variety of non-uniform grids and time steps.

Upon solving Eqn. 5, we calculate the deposition rate for each time step. This method allows for molecular level interaction with the surface, resulting in deposition without the need to prescribe a deposition velocity. We include interactive surface chemistry, which can lead to release of species from the ground into the gas phase. More details are provided in the Section 3.3.

\subsection{Model setup for CalNex campaign}

PACT-1D was initialized using both model data (from WRF-Chem, MOZART, MEGAN, and CAMS) and observational data from the CalNex 2010 campaign (Table 1). The 24hour period from May 26, 2010 18:00 through May 27, 2010 17:00 was used as model spin up. The model subdivides the lowest $5000 \mathrm{~m}$ of the atmosphere into 26 grid cells, with model grid box upper boundaries at: $1 \times 10^{-3}, 0.01,0.1,1,3,6,10,20,33,50,78,90,110$, $121,150,175,255,300,556,750,1000,1500,2000,3000,4000$, and $5000 \mathrm{~m}$. A 20 second chemical time step was used for each model run.

Time varying profiles of temperature, relative humidity, and pressure were extracted from a WRF-Chem model run for CalNex (Kim et al., 2016), which provided values above 180 m. These were interpolated onto the 1D vertical grid and measured meteorological data was used to create a profile to the surface. Below $180 \mathrm{~m}$, temperature was calculated based on $10 \mathrm{~m}$ measurements of wind speed and temperature, the measured boundary layer height, and atmospheric stability parameters. Relative humidity was given a constant value equal to the measurements at $10 \mathrm{~m}$ and pressure was calculated using the surface pressure and scale height. We take eddy diffusion coefficients $(\mathrm{Kz})$ from WRFChem as well (Kim et al., 2016). These values start at $\sim 50 \mathrm{~m}$ and a log interpolation was 
implemented to parameterize $\mathrm{Kz}$ values to the ground. The vertical mixing considered boundary layer height variation over the three day period, which is explicitly calculated via the planetary boundary layer (PBL) parameterization used within WRF-Chem.

Aerosol number concentration profiles were initialized using data from the TSI Scanning Mobility Particle Sizer (SMPS) instrument. Within the boundary layer, the number concentration was set equal to the measurements at $10 \mathrm{~m}$ and then decreased exponentially to one fifth of this value in the top layer of the model. The aerosol radius was assumed to be constant at $150 \mathrm{~nm}$, following the study by Tsai et al. (2014). Photolysis rates were initialized using the Tropospheric Ultraviolet-Visible (TUV) radiation model (v5.0) which was run for our test date and location. To account for clouds, measured $\mathrm{NO}_{2}$ photolysis rates were used to scale the TUV values for all species.

Input anthropogenic emissions are based on the U.S. Environmental Protection Agency (EPA) National Emission Inventory (NEI) and the Fuel-based Inventory for motor Vehicle Emission (FIVE), which have been processed for use in WRF-Chem (Kim et al., 2016). Biogenic emissions are from the MEGAN model for May 2010. Anthropogenic $\mathrm{NO}_{x}$ emissions were emitted between 0.1-1 $\mathrm{m}$ and VOC emissions were emitted between 0.1-10 $\mathrm{m}$. The emissions were scaled so that model concentrations matched those observed by the LP-DOAS and in-situ observations, using realistic emission injection altitudes for different emission source types. In some cases, the emissions are scaled by up to $50 \%$ in order to reproduce realistic $\mathrm{VOC}$ and $\mathrm{NO}_{x}$ concentrations, as well as $\mathrm{NO}_{2}$ concentration profiles. Emissions scaling is needed to reproduce observations due to the fine model vertical resolution, which employs a much higher resolution grid vertically than typical 3D chemical transport models. 3D models quickly dilute these emissions into larger volumes of air resulting in lower concentrations of species that are directly emitted which impacts ozone chemistry and other non-linear atmospheric chemical cycling. In addition, the WRFChem emissions are general values for either weekday or weekend and have large uncertainties when modeling specific dates and events at high time resolution. This period includes the weekend (Saturday 5/29 and Sunday 5/30) before a major holiday (Memorial day).

Soil NO emissions are taken from the Copernicus Atmospheric Monitoring Service (CAMS) global and regional emissions dataset, which considers surface type, for May 2012 near Pasadena, CA (Simpson et al., 2014; Granier et al., 2019). Anthrogpogenic 
HONO emissions were included using an emission ratio of $\mathrm{HONO} / \mathrm{NO}_{x}=0.003$ (Kurtenbach et al., 2001). A range of 0.003-0.008 is reported in literature (Kirchstetter et al., 1996; Kurtenbach et al., 2001; Neuman et al., 2016; Kramer et al., 2019) and due to the lower number of diesel engine vehicles in the United States compared to Europe where many of these studies were conducted, we chose a value at the lower end of this range.

To better simulate the urban atmosphere, chlorine chemistry and parameterized nitrate aerosol chemistry were added to the RACM2 mechanism. Aerosol nitrate is formed through uptake of $\mathrm{HNO}_{3}$ and $\mathrm{N}_{2} \mathrm{O}_{5}$, with aerosol uptake coefficients of 0.1 and 0.02 , respectively. Partitioning between gas phase $\mathrm{HNO}_{3}$ and aerosol nitrate is based on the study by Guo et al. (2017), who found a campaign average partitioning ratio, $\epsilon\left(\mathrm{NO}_{3}{ }^{-}\right)$, of $39 \%$ for PM1 during CalNex.

$$
\epsilon\left(\mathrm{NO}_{3}^{-}\right)=\frac{\mathrm{NO}_{3}^{-}}{\mathrm{HNO}_{3}+\mathrm{NO}_{3}^{-}}
$$

Similar to photolysis of $\mathrm{HNO}_{3}$ on the ground, nitrate in aerosol can also photolyze to give HONO. This is added to the mechanism with a rate 45 times that of gas phase nitric acid (Zhou et al., 2003; Karamchandani et al., 2014).

\subsection{Interactive treatment of surface chemistry}

The proposed HONO formation mechanisms occur at the ground, therefore we implemented detailed surface heterogeneous chemistry within PACT-1D. Deposition is calculated from the number of molecular collisions with the ground and an uptake coefficient, allowing for molecular level chemical conversions and surface emissions. The quantity of species available for reactions on the ground was initialized using a model spinup of four days to achieve near steady state conditions. The HONO formation mechanisms described in Section 1.1 were added to PACT-1D with model implementation described below.

\subsection{1 $\mathrm{NO}_{2}$ hydrolysis}

Conversion of $\mathrm{NO}_{2}$ to $\mathrm{HONO}$ on the ground is implemented into the model using reaction $\mathrm{R} 4$. $\mathrm{NO}_{2}$ deposition is tracked and for every two molecules deposited, one HONO molecule is released from the surface and one $\mathrm{HNO}_{3}$ molecule is added to the surface storage term. The ground $\mathrm{NO}_{2}$ uptake coefficient $\left(\gamma_{\mathrm{NO}_{2}, \text { dark }}\right)$ is set at $1 \times 10^{-5}$ (Trick, 2004). 


\subsubsection{Photo-enhanced $\mathrm{NO}_{2}$ conversion}

The photo-enhanced conversion of $\mathrm{NO}_{2}$ to $\mathrm{HONO}$ is included using the parameterization by Wong et al. (2013). In Wong et al. (2012) and Wong et al. (2013), daytime HONO concentrations in Houston, Texas correlated with solar irradiance and they determined that the reactive uptake coefficient for $\mathrm{NO}_{2}$ could be parameterized with a cubic dependence on the $\mathrm{NO}_{2}$ photolysis rate (Eqn. 7).

$$
\gamma_{\mathrm{NO}_{2}, \text { photo }}=6 x 10^{-5} \frac{J_{\mathrm{NO}_{2}}^{3}}{J_{\mathrm{NO}_{2}, \text { noon }}^{3}}
$$

$6 \times 10^{-5}$ is the maximum reactive uptake coefficient. The average noontime photolysis rate for $\mathrm{NO}_{2}\left(J_{N O 2, n o o n}\right)$ during the four days that we focused on (May 26-30 2010) is $7 \times 10^{-3} \mathrm{~s}^{-1}$. This photo-enhanced $\mathrm{NO}_{2}$ uptake occurs in addition to dark uptake, giving an effective $\mathrm{NO}_{2}$ deposition rate $\left(\nu_{d, \mathrm{NO}_{2}}\right)$ according to the following equation, where $\nu$ is the mean molecular speed. $\nu_{d, \mathrm{NO}_{2}}$ drives $\mathrm{NO}_{2}$ deposition in the model.

$$
v_{d, \mathrm{NO}_{2}}=\frac{1}{4} v \gamma_{\mathrm{NO}_{2}, \text { dark }}+\frac{1}{4} v \gamma_{\mathrm{NO}_{2}, \text { photo }}
$$

\subsubsection{Surface nitric acid/nitrate photolysis}

Following the modeling study of Sarwar et al. (2008), we parameterize photolysis of surface adsorbed $\mathrm{HNO}_{3}$ using the following reaction.

$$
\mathrm{HNO}_{3(\mathrm{ads})}+\mathrm{h} \nu \rightarrow 0.5 \mathrm{HONO}_{(\mathrm{ads})}+0.5 \mathrm{NO}_{2(\mathrm{ads})}
$$

Surface $\mathrm{HNO}_{3}$ is initialized in the model and it's concentration is updated considering deposition and surface chemistry. $\mathrm{HONO}$ and $\mathrm{NO}_{2}$ produced in R11 are released into the lowest model layer via desorption. $\mathrm{HNO}_{3}$ deposition to the ground is calculated using an uptake coefficient of 0.1 . The photolysis rate constant of this reaction $\left(J_{\mathrm{HNO}_{3}, \text { surf }}\right)$ is set to 45 times that of gas-phase $\mathrm{HNO}_{3}$ (Zhou et al., 2003; Karamchandani et al., 2014), giving noon time values of $2.0 \times 10^{-5} \mathrm{~s}^{-1}$ on May 27 and $2.5 \times 10^{-5} \mathrm{~s}^{-1}$ on May 28 and 29. These rate constants are in accordance with the value of $2.5 \times 10^{-5} \mathrm{~s}^{-1}$ reported by Zhou et al. (2003), and are also used for aerosol nitrate photolysis. The scaling factor of 45 is also consistent with that used by Fu et al. (2019) and Liu et al. (2021), who cal-

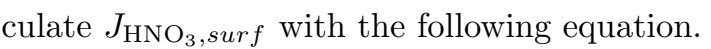




$$
J_{\mathrm{HNO}_{3}, \text { surf }}=\frac{3.4 \times 10^{-5}}{7 \times 10^{-7}} J_{\mathrm{HNO}_{3}}
$$

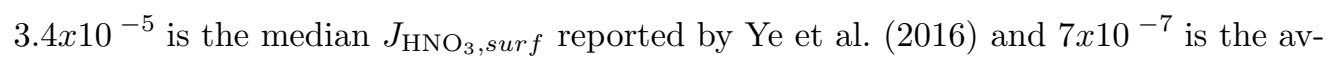
erage noontime $J_{\mathrm{HNO}_{3}, \text { gas }}$.

\subsubsection{HONO uptake, nocturnal storage, acid displacement}

Uptake to the ground is an important loss for atmospheric HONO, especially at night. Once deposited, it forms surface nitrite through R9 and a similar reaction occurs with $\mathrm{HNO}_{4}$. According to VandenBoer et al. (2015), this nitrite can be recycled back to gaseous HONO when displaced by a strong acid. In the model we assume that all HONO and $\mathrm{HNO}_{4}$ deposited to the ground is converted to nitrite. Every $\mathrm{HNO}_{3}$ molecule deposited then results in a HONO molecule emitted to the lowest model layer. The uptake coefficients for $\mathrm{HONO}, \mathrm{HNO}_{4}$, and $\mathrm{HNO}_{3}$ are $1 \times 10^{-4}, 0.01$, and 0.1 , respectively. To ensure there is a sufficient amount of nitrite present to be displaced, it's concentration is tracked and if it falls below a monolayer $\left({ }^{\sim} 1 \times 10^{13}\right.$ molec $\left.\mathrm{cm}^{-2}\right)$, the HONO source is scaled by $\frac{\left[\mathrm{NO}_{2}^{-}\right]}{1 \times 10^{13}}$.

\subsubsection{Biogenic emissions}

Oswald et al. (2013) determined that HONO can contribute up to $50 \%$ of reactive nitrogen released from soil, comparable to soil NO emissions. Soil NO emissions are included in the model as input. We assume that NO and HONO make up the majority of reactive nitrogen and therefore set HONO emissions equal to NO as an upper limit.

\section{Results and discussion}

We use PACT-1D to simulate HONO levels during the CalNex campaign and analyze the importance of ground sources. An overview of each model run is provided in Table 2 and each is discussed below.

\subsection{Model run without HONO surface chemistry (NoSurf run)}

A model run (NoSurf) was first performed to investigate HONO concentrations without ground surface chemistry. In this run, HONO was impacted by gas phase chemistry, 
Table 2. Overview of PACT-1D model runs

\begin{tabular}{|l|l|}
\hline Model Run & Description \\
\hline NoSurf & $\mathrm{HONO}$ chemistry on the ground not included \\
Base & $\mathrm{HONO}$ chemistry on the ground included \\
Sens1 & $\gamma_{\mathrm{NO}_{2}, \text { max }}$ decreased by $50 \%, J_{\mathrm{HNO}_{3}, \text { surf }}$ increased by $25 \%$ \\
Sens2 & $\gamma_{\mathrm{NO}_{2}, \text { max }}$ increased by $2 \mathrm{x}, J_{\mathrm{HNO}_{3}, \text { surf }}$ decreased by $20 \%$ \\
Sens3 & $\gamma_{\mathrm{NO}_{2}, \text { max }}$ decreased by $90 \%, J_{\mathrm{HNO}_{3}, \text { surf }}$ increased by $60 \%$ \\
Sens4 & $\gamma_{\mathrm{NO}_{2}, \text { max }}$ increased by $5 \mathrm{x}, J_{\mathrm{HNO}_{3}, \text { surf }}$ decreased to gas phase $J_{\mathrm{HNO}_{3}}$ \\
\hline
\end{tabular}

direct emissions, deposition to the ground with an uptake coefficient of $1 \times 10^{-4}$, uptake on aerosol surfaces with an uptake coefficient of $1 \times 10^{-3}$, and formation from aerosol nitrate photolysis. HONO levels at $3 \mathrm{~m}$ were compared to the CIMS measurements (Figure 3, bottom right). Modeled HONO, shown in orange, remained around $0.1 \mathrm{ppb}$ or lower during daytime periods. May 28 and 29 showed an early morning peak between 0.15 $0.3 \mathrm{ppb}$. Daytime and nighttime concentrations for all three days were significantly lower than observations, indicating that gas phase formation, direct emissions, and aerosol nitrate photolysis cannot completely explain HONO levels and that an additional source is required.

\subsection{Model results with interactive surface chemistry (Base run)}

When heterogeneous HONO formation sources at the ground were implemented in PACT-1D (Base run), the model matched observations much better (Figure 3). The model captures the general trend and values of major species including $\mathrm{NO}_{x}, \mathrm{HO}_{x}$, and $\mathrm{O}_{3}$. Due to lack of horizontal advection in PACT-1D, however, there are some discrepancies related to changes in air mass, for example near midnight on May 30. The model also misses some of the afternoon $\mathrm{NO}_{x}$ peaks, which are due to advection of polluted air from downtown Los Angeles. These dates correspond to the start of the Memorial Day holiday weekend as well, making traffic emissions more difficult to estimate.

The overprediction of $\mathrm{OH}$ and underprediction of $\mathrm{HO}_{2}$ in $\mathrm{PACT}-1 \mathrm{D}$ is consistent with results from Griffith et al. (2016) and is likely due to missing radical processes in the RACM2 mechanism. Griffith et al. (2016) suggests that reactivity between $\mathrm{OH}$ and 

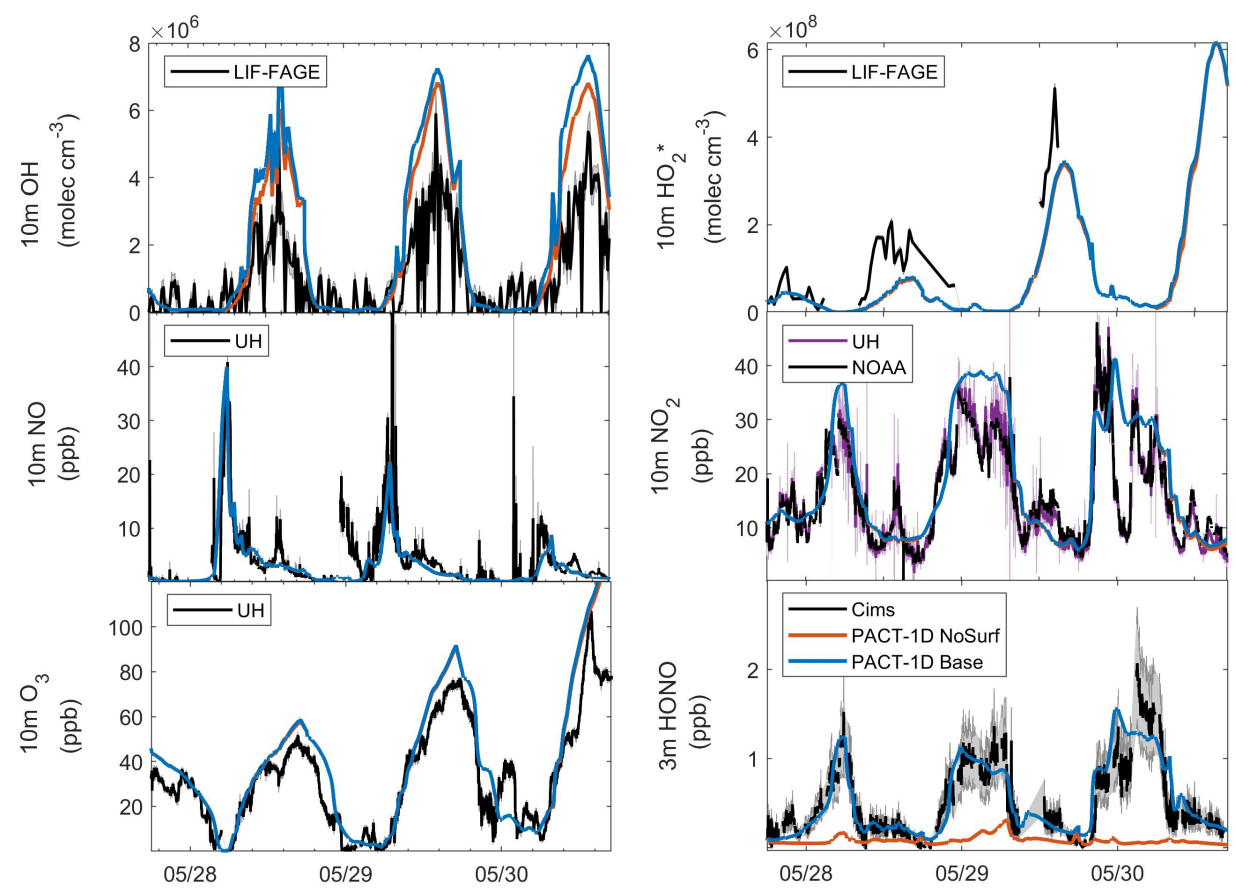

Figure 3. Overview plot showing NoSurf (orange) and Base (blue) model results compared to observations from May 27, 2010 18:00 through May 30, 2010 18:00. Measurement details are included in Table 1. $\mathrm{HO}_{2} *$ is $\mathrm{HO}_{2}+0.3 \mathrm{RO}_{2}$, following Griffith et al. (2016).

saturated hydrocarbons and $\mathrm{OH}$ and aldehydes is under predicted in the mechanism which leads to an over prediction of $\mathrm{OH}$ and under prediction of $\mathrm{HO}_{2}$. Similar results were reported by Wolfe et al. (2016), who found that production of $\mathrm{HO}_{2}$ from reactions of $\mathrm{OH}$ with $\mathrm{HCHO}, \mathrm{CO}$ and other hydrocarbons was too slow in the RACM2 mechanism to accurately capture $\mathrm{OH}$ and $\mathrm{HO}_{2}$ observations.

The diurnal HONO trend is captured in the Base run, showing mixing ratios increasing over night, followed by a sharp decrease in the early morning. Concentrations are substantially higher compared to the NoSurf run, with daytime values ranging between 0.1-0.5 ppb and night time values increasing to 1.2-1.6 ppb. Modeled HONO does not capture the early morning peaks around 6:00-7:00 on May 29 and 30. This and the delayed decrease in HONO during the morning of May 30 indicate that the morning mixing may not be completely accurate in the model. A delay in morning boundary layer growth can prevent HONO formed overnight from mixing away from the surface. The 
quick changes in observed $\mathrm{O}_{3}, \mathrm{NO}_{2}$, and $\mathrm{NO}$ also indicate that there are air mass changes that the model cannot capture. Overall, these results show very good agreement between model and observations and show that a heterogeneous HONO surface source is necessary to simulate realistic atmospheric HONO levels. The mechanisms implemented here appropriately describe this heterogeneous source during CalNex.

\subsection{HONO vertical profiles}

Since HONO photolyzes quickly during transport away from the ground where it is formed, vertical profiles must be considered to understand HONO's sources and its total impact to air quality in the boundary layer. Observed profiles were constructed by vertically interpolating between the NOAA CIMS measurements at $3 \mathrm{~m}$ and the LPDOAS measurements at $55.5 \mathrm{~m}, 99.5 \mathrm{~m}, 188 \mathrm{~m}$, and $405.5 \mathrm{~m}$. The CIMS and LP-DOAS instruments showed excellent agreement in another field experiment (UBWOS 2012). We are therefore confident that the two datasets can be combined to construct vertical concentration profiles of HONO. Figure 4 shows the observed profile compared to PACT1D for the entire 3 day period and Figure 5 shows select hours between May 27 18:00 and May 28 17:00.

In the observed profile, the highest HONO concentrations are typically at the surface, which is consistent with vertical profiles measured in other field campaigns (Kleffmann et al., 2003; Villena et al., 2011; Wong et al., 2011, 2012; Young et al., 2012; VandenBoer et al., 2013; Tsai et al., 2018). The quick decay in HONO with altitude in the lowest $100 \mathrm{~m}$, especially during the day, emphasizes the importance of vertical profile measurements and modeling. HONO's role in boundary layer chemistry can easily be over or under estimated if measurements at a single altitude are used. In particular, this can have a significant impact on $\mathrm{OH}$ production rates, which will be discussed in the following section. Similar to other studies, we conclude that these profiles provide evidence for a ground source of HONO. The underestimation of HONO in the NoSurf run (Figure 5, right), shows that direct emissions cannot be the primary ground source. Accurately implementing the heterogeneous HONO surface sources allowed us to better model HONO both near the surface and at higher altitudes.

The underestimation of HONO in the NoSurf run (Figure 5, right), which includes heterogeneous HONO formation from aerosol nitrate only, also shows that aerosol sources 


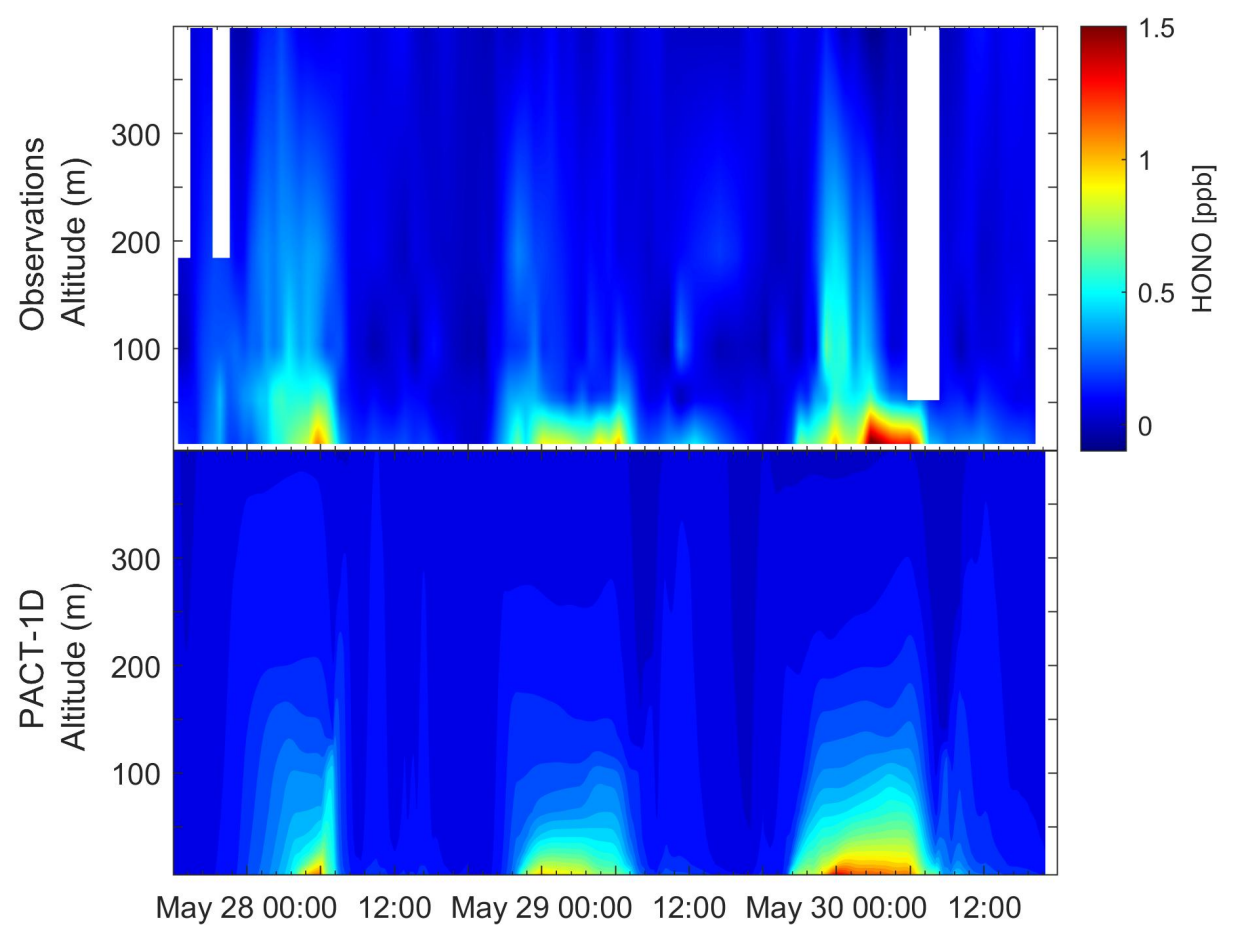

Figure 4. Comparison of HONO vertical concentration profiles between observations (top) and model (bottom), from May 27 18:00 to May 30 17:00. The observed profile is constructed from LP-DOAS data and NOAA CIMS data.

of HONO are less significant than ground sources. The aerosol source shows a diurnal trend, peaking in the early afternoon and decreasing to zero at night. In the Base run, the source peaks near $7 \times 10^{5}$ molec $\mathrm{cm}^{-3} \mathrm{~s}^{-1}$ on May $28,9 \times 10^{5}$ on May 29 , and $8 \times 10^{5}$ on May 30, within the LP-DOAS altitude range (50-400 m). Lower values on May 28 are due to smaller photolysis rates and lower aerosol number concentrations that day. Aerosol nitrate concentrations are under predicted compared to observations on this day as well so the values reported by our model are likely too low. On May 29, modeled aerosol nitrate concentrations are slightly higher than observed, indicating that the HONO aerosol source may be slightly over predicted as well. The values we report are generally consistent with other studies in urban areas, including Wong et al. (2013) who reports noontime values of 1.0-1.7x $10{ }^{6}$ molec $\mathrm{cm}^{-3} \mathrm{~s}^{-1}$ in Houston, Texas. Our values are lower than those reported in more polluted cities with larger available aerosol surface area. Liu et al. (2021), for example, found approximately $1 \mathrm{ppb} \mathrm{hr}^{-1}\left(6.9 \times 10^{6} \mathrm{molec}^{-3} \mathrm{~s}^{-1}\right)$ of 


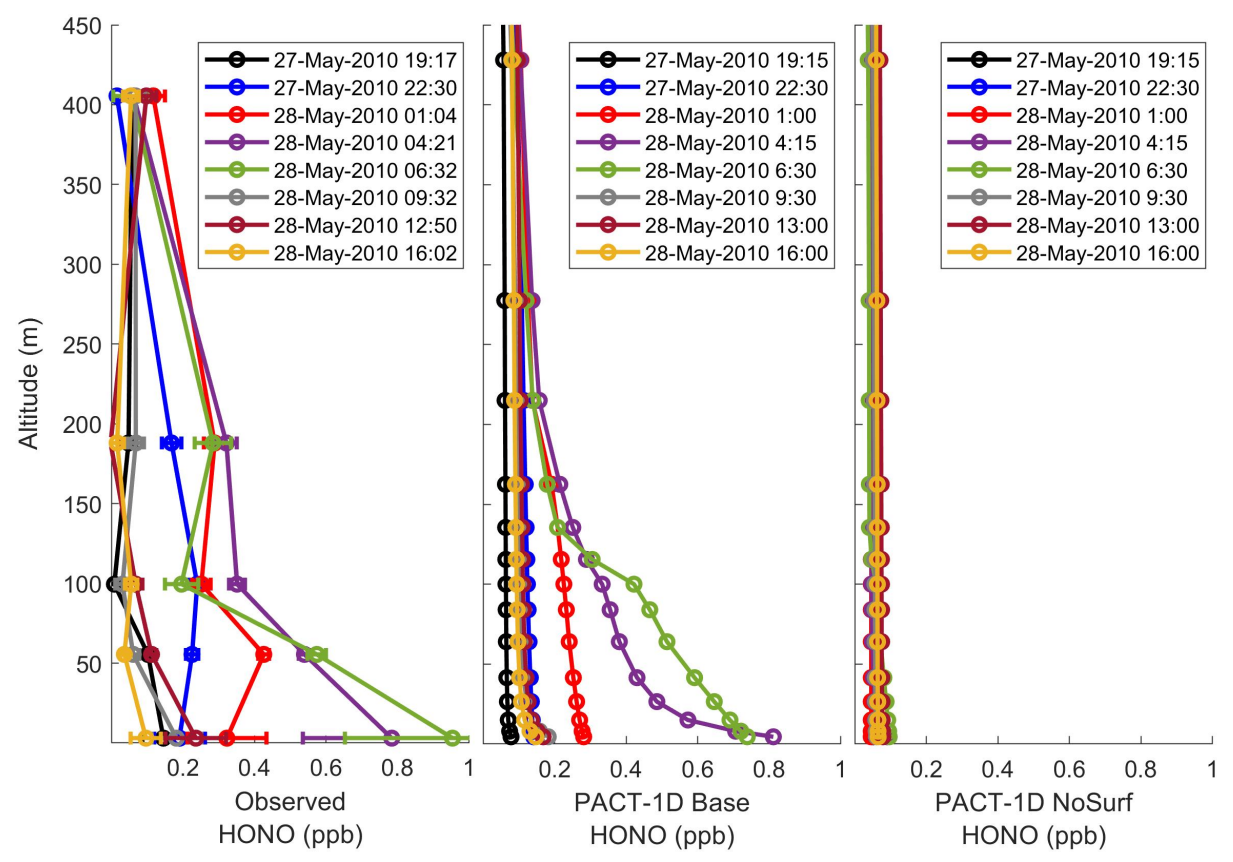

Figure 5. Comparison of HONO vertical concentration profiles between observations and model from May 27 to 28 . The left panel is the observed profile, the middle is the PACT-1D Base run including surface chemistry, and the right panel is the PACT-1D NoSurf run excluding surface chemistry. The observed profile is constructed from LP-DOAS data (top four data points) and NOAA CIMS data (lowest data point).

HONO could be formed from aerosol sources at noon in Beijing in summer. The higher rates in Beijing are likely due to the higher aerosol loading in that study.

Net vertical transport rates of $\mathrm{HONO}$ from below are more variable from day to day but, in general, are greater than or about equal to HONO production from aerosol nitrate. For most of the three day period, the primary source of HONO below $500 \mathrm{~m}$ is upward transport from the surface (Figure 6). The large difference in surface area between aerosols and the ground can explain the greater importance of ground sources and is in agreement with other studies (Kalberer et al., 1999; Kleffmann et al., 2003; Vogel et al., 2003; Stemmler et al., 2007). Compared to observations, daytime HONO levels between 50-400 $\mathrm{m}$ in the Base run tend to be over predicted. This may indicate that the sources aloft (formation on aerosols and transport from below) are too high. There is uncertainty in the photolysis rate for the aerosol source in the model, and the verti- 

sponsible for the disagreement.

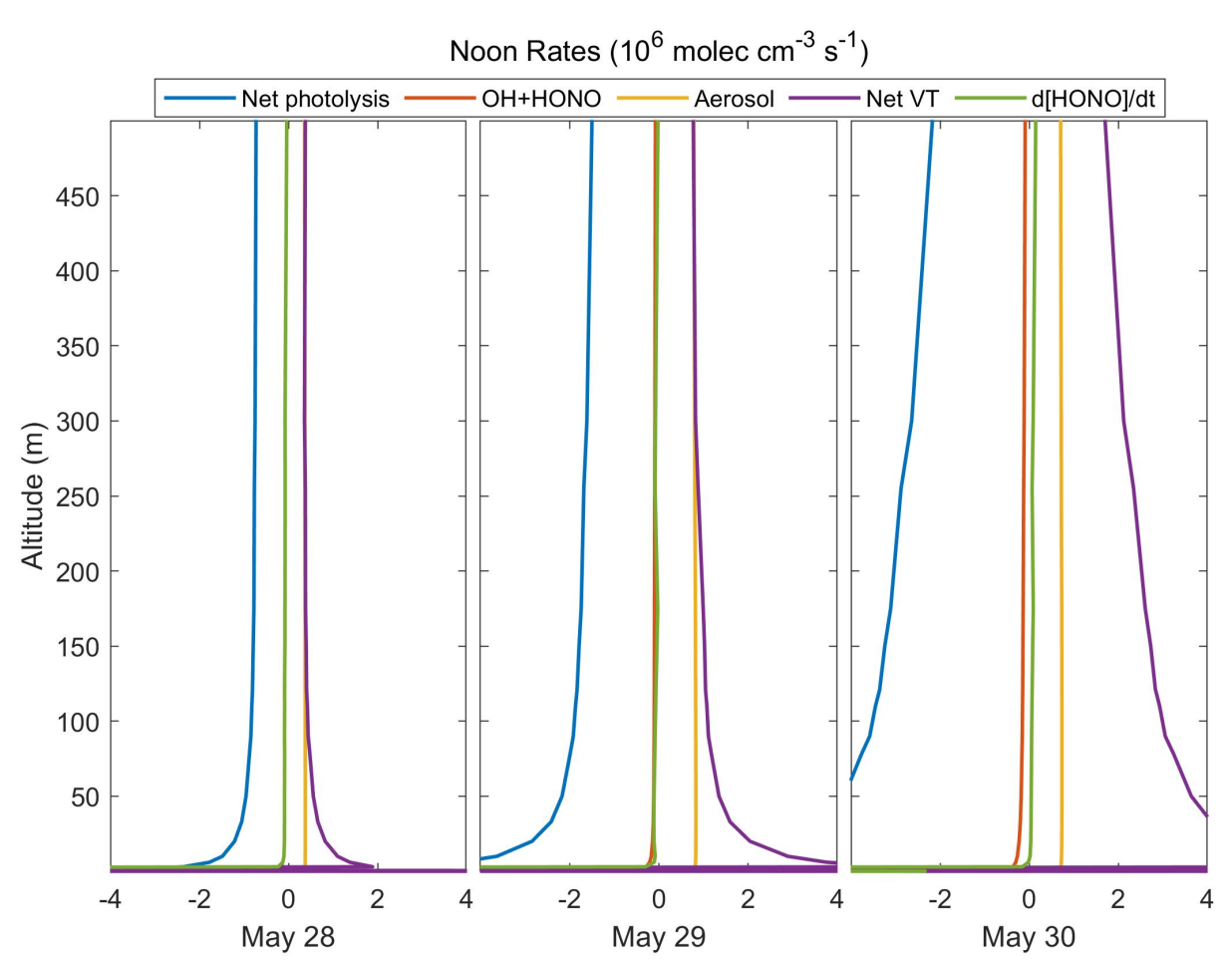

Figure 6. Noon time HONO budget for May 28 (left), 29 (middle), and 30 (right) from the Base run. Rates are reported in molec $\mathrm{cm}^{-3} \mathrm{~s}^{-1}$ and include net photolysis (HONO photolysis minus formation from the $\mathrm{OH}+\mathrm{NO}$ reaction), loss via the $\mathrm{HONO}+\mathrm{OH}$ reaction, formation from aerosol nitrate photolysis, net vertical transport, and the HONO concentration change with time.

cal transport from the ground. Consequently, it is currently unclear which process is re-

\subsection{Primary $\mathrm{HO}_{x}$ production}

To determine the importance of HONO to the radical budget, primary HOx production $\left(\mathrm{P}_{\mathrm{HOx}}\right)$ was calculated for the Base run and measurements. We considered three major primary $\mathrm{HO}_{x}$ production pathways, $\mathrm{HONO}$ photolysis, $\mathrm{HCHO}$ photolysis, and $\mathrm{O}_{3}$ photolysis followed by reaction of $\mathrm{O}\left({ }^{1} \mathrm{D}\right)$ with $\mathrm{H}_{2} \mathrm{O}$. Since HONO levels change quickly with altitude, as seen in the previous section, we again used vertical profiles to calculate $\mathrm{P}_{\mathrm{HOx}}$. In addition to HONO measurements, the LP-DOAS observed vertical profiles of $\mathrm{HCHO}$ and $\mathrm{O}_{3}$. These were combined with the $3 \mathrm{~m}$ CIMS measurements of HONO, and the University of Houston's (UH) $10 \mathrm{~m} \mathrm{O}_{3}$ measurements to construct concentration profiles. $10 \mathrm{~m}$ measurements of photolysis rates, temperature, and relative humid- 
ity (Table 1 ) were used to calculate $\mathrm{P}_{\mathrm{HOx}}$, assuming the values are constant over the altitude range considered here $(0-450 \mathrm{~m})$. Figure 7 shows vertical profiles of $\mathrm{P}_{\mathrm{HOx}}$ from observations (solid lines) and model (dashed lines). These values are averages from 10:00 am - 12:00 pm on May 28, 2010.

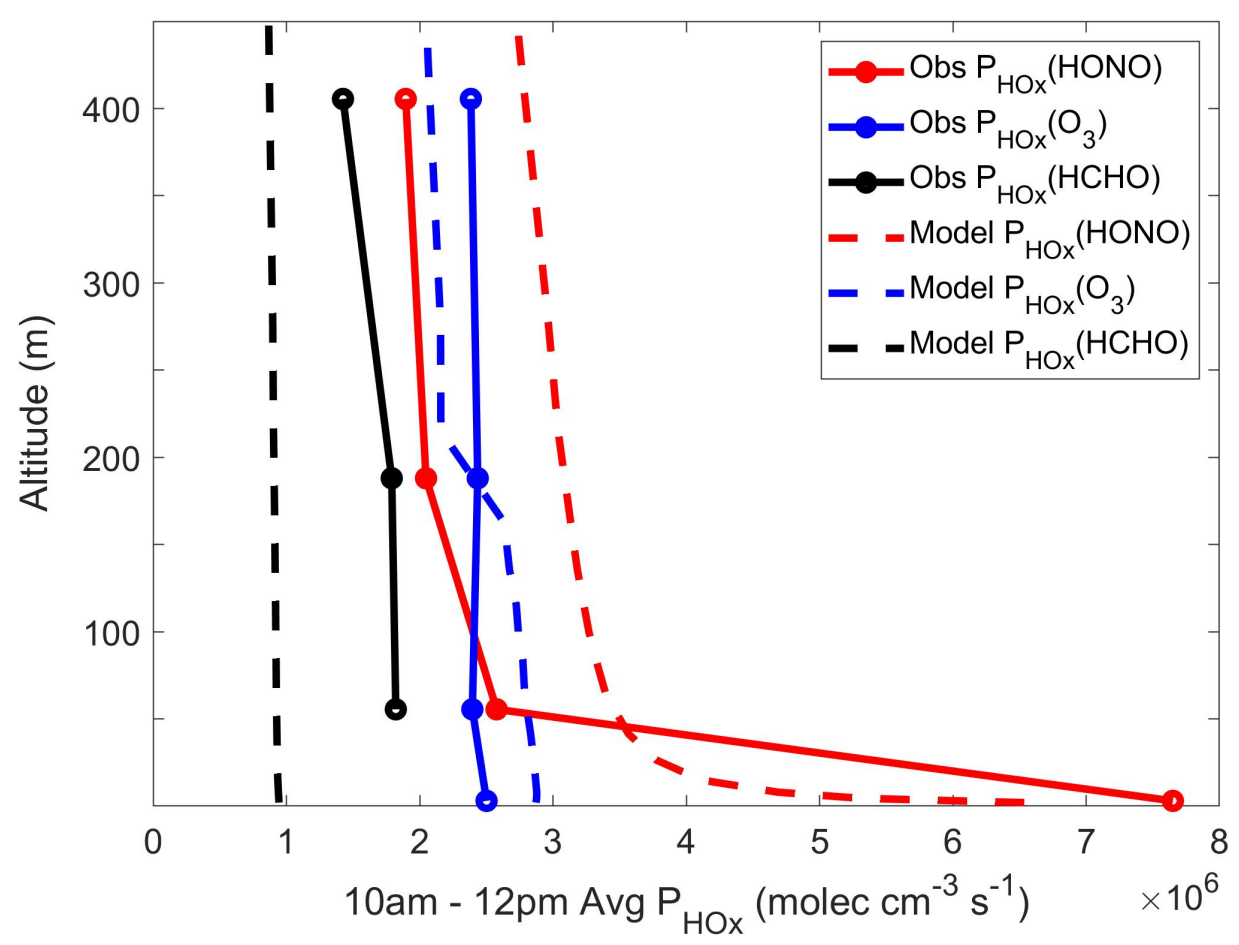

Figure 7. Primary $\mathrm{HO}_{x}$ production due to $\mathrm{HONO}$ (red), $\mathrm{O}_{3}$ (blue), and HCHO (black). Observations are shown as dotted lines and model data from the Base run is shown as solid lines. Values are averaged between 10am-12pm on May 28, 2010.

In both PACT-1D and observations, the contribution to $\mathrm{P}_{\mathrm{HOx}}$ from $\mathrm{HCHO}$ and $\mathrm{O}_{3}$ remains relatively constant with height, with higher values for $\mathrm{O}_{3}$. PACT-1D underestimates $\mathrm{P}_{\mathrm{HOx}}$ from $\mathrm{HCHO}$ compared to the observations, but captures the $\mathrm{O}_{3}$ contribution well. Comparing HCHO LP-DOAS measurements to the model shows that PACT1D under predicts $\mathrm{HCHO}$ levels at these altitudes, which leads to the under prediction of $\mathrm{P}_{\mathrm{HOx}}(\mathrm{HCHO})$.

Both observations and PACT-1D show that HONO photolysis is dominant near the surface, contributing 2-3 times more than $\mathrm{O}_{3}$ below $10 \mathrm{~m}$. $\mathrm{P}_{\mathrm{HOx}}(\mathrm{HONO})$ decreases quickly moving away from the surface, following the trend seen in the HONO concentration pro- 
file. PACT-1D underestimates $\mathrm{P}_{\mathrm{HOx}}(\mathrm{HONO})$ compared to the observations at the surface by about $15 \%$ compared to observations, and over predicts at higher altitudes by 25-35\%. The model also underestimates HONO concentrations at the surface and over predicts them aloft during this time period (Figure 5) which can explain this difference in $\mathrm{P}_{\mathrm{HOx}}(\mathrm{HONO})$. The discrepancy between model and observations, for both the concentration and $\mathrm{P}_{\mathrm{HOx}}(\mathrm{HONO})$, is likely due to the high sensitivity of HONO to the vertical mixing or an over prediction of the HONO aerosol source, as discussed above.

A study by Griffith et al. (2016) found that during the CalNex campaign, HONO photolysis contributed $26 \%$ to the total radical production rate on weekends and holidays and $29 \%$ on weekdays. Using these average values, their $\mathrm{P}_{\mathrm{HOx}}(\mathrm{HONO})$ between 10:00 am and 12:00 pm ranged from about $5 \times 10^{6}$ and $8 \times 10^{6}$ molec $\mathrm{cm}^{-3} \mathrm{~s}^{-1}$. They note that these values are most appropriate for $10 \mathrm{~m}$ altitude where measurements were recorded, and are consistent with the values we report here at low altitudes. HCHO photolysis contributed $9-10 \%$ to the total radical production, giving rates between $1.5 \times 10^{6}$ and $3 \times 10^{6}$ molec $\mathrm{cm}^{-3} \mathrm{~s}^{-1}$. The observations reported here are in agreement with these values, but again PACT-1D under predicts $\mathrm{P}_{\mathrm{HOx}}(\mathrm{HCHO})$ due to the $\mathrm{HCHO}$ concentration being too low. $\mathrm{O}_{3}$ photolysis contributed $11-14 \%$, with rates of $2 \times 10^{6}-4.5 \times 10^{6}$ molec $\mathrm{cm}^{-3} \mathrm{~s}^{-1}$, matching our values well.

\subsection{HONO source mechanisms}

The HONO surface formation mechanisms added to PACT-1D in the Base run provided an additional source of up to $2.5 \times 10^{11}$ molecules $\mathrm{cm}^{-2} \mathrm{~s}^{-1}$ during the day and up to $5 \times 10^{10}$ molecules $\mathrm{cm}^{-2} \mathrm{~s}^{-1}$ during the night. Figure 8 shows the source rate for our three day period, including the contributions from individual mechanisms. Values remained relatively constant throughout each of the nights around $1 \times 10^{10}$ to $5 \times 10^{10}$ molecules $\mathrm{cm}^{-2} \mathrm{~s}^{-1}$ and then increased quickly in the early morning as photolytic formation mechanisms become effective. Our values are higher than source rates reported by other field studies, which include a forest canopy (Zhang et al., 2009; Zheng et al., 2011), an agricultural site (Ren et al., 2011), and polluted rural site (Tsai et al., 2018). These studies report average noontime fluxes between $1 \times 10^{10}$ to $3 \times 10^{10}$ molecules $\mathrm{cm}^{-2} \mathrm{~s}^{-1}$, measured at 10 $20 \mathrm{~m}$ altitudes. Our surface flux is provided directly at the ground which likely explains the higher values. Loss of HONO through photolysis or deposition back to the ground decreases the amount that is transported to higher altitudes. We calculated the flux of 


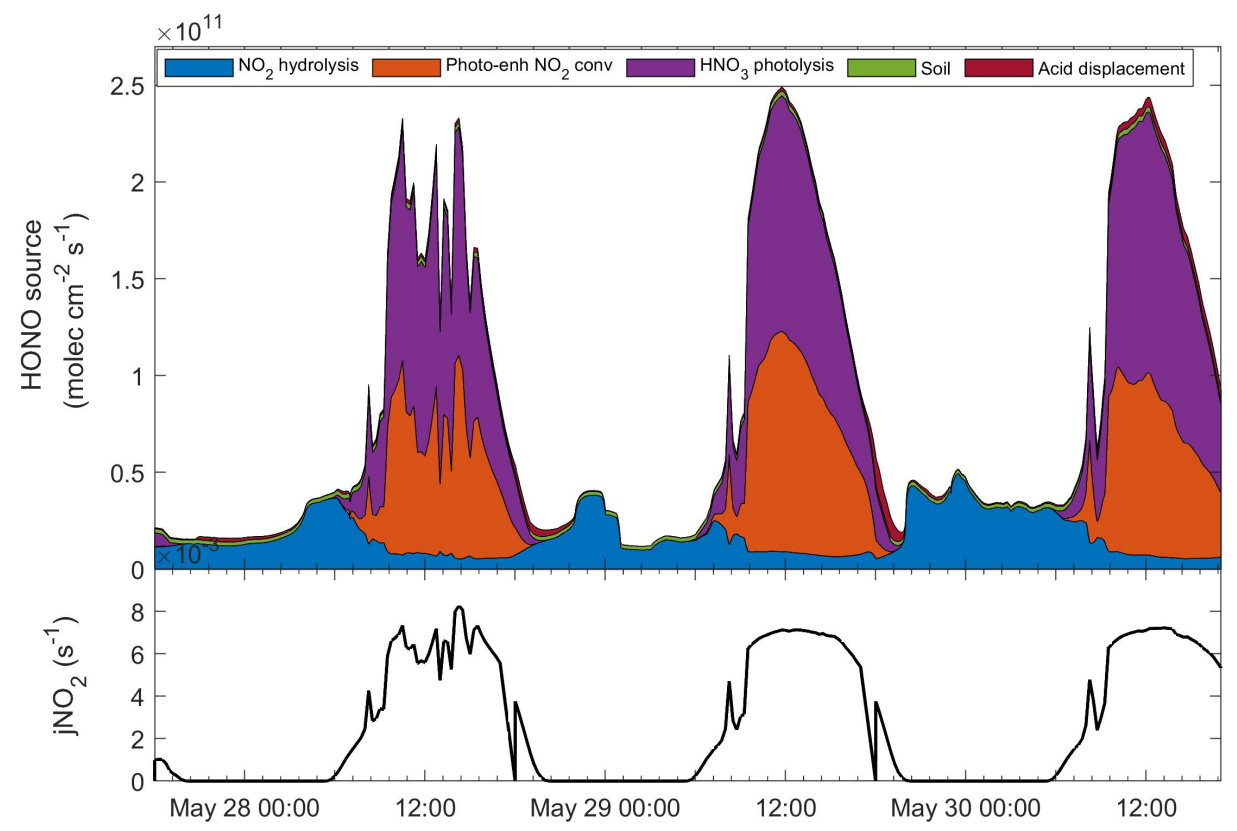

Figure 8. Contribution of individual mechanisms to the total HONO surface source in the Base run, from May 27, 2010 18:00 through May 30, 2010 17:00. The $10 \mathrm{~m} \mathrm{NO}_{2}$ photolysis rate for the 3 day period is shown in the lower panel.

HONO across $10 \mathrm{~m}$ in the model and found noontime values of $5 \times 10^{10}$ molecules $\mathrm{cm}^{-2} \mathrm{~s}^{-1}$ for May 28 and 29 and $1.1 \times 10^{11}$ molecules $\mathrm{cm}^{-2} \mathrm{~s}^{-1}$ for May 30. These are in better agreement with previous studies. Our urban site likely has a higher HONO source due to higher $\mathrm{NO}_{2}$ concentrations and deposition, and higher surface $\mathrm{HNO}_{3}$ concentrations. 
found daytime $\mathrm{HONO}$ production did not vary with weekday/weekend changes in $\mathrm{NO}_{2}$. They suggested therefore that $\mathrm{NO}_{2}$ conversion is not the dominant HONO formation pathway. Although $\mathrm{HNO}_{3}$ can also show a dependence on $\mathrm{NO}_{x}$ levels, its deposition and subsequent photolysis occur on a longer time scale which would not necessarily correlate with atmospheric $\mathrm{NO}_{2}$ levels. Baergen and Donaldson (2016) suggests that $\mathrm{HNO}_{3}$ photolysis on urban grime and it's dependence on relative humidity would also cause a discrepancy between $\mathrm{NO}_{2}$ and $\mathrm{HONO}$ production. Our results therefore support the findings by Pusede et al. (2015).

It is currently unclear however, why these differ from the study performed by Wong et al. (2013) in Houston, Texas. They found that photo-enhanced $\mathrm{NO}_{2}$ conversion was the dominant $\mathrm{HONO}$ source based on a clear correlation between $\mathrm{HONO}$ and $\mathrm{NO}_{2}$ levels. It is possible that surface $\mathrm{HNO}_{3} / \mathrm{NO}_{3}{ }^{-}$concentrations are higher in Los Angeles, giving more importance to its photolytic source. The scarcity of significant rain events in Southern California may cause a buildup of $\mathrm{HNO}_{3}$ on surfaces, whereas the much more frequent precipitation in Houston can lead to surface adsorbed species being washed away. Guo et al. (2017) did find that particle nitrate and $\mathrm{HNO}_{3}$ concentrations during CalNex were higher than measurements from summertime campaigns in the southeast United States. They suggest this is due to the higher $\mathrm{NO}_{x}$ versus $\mathrm{SO}_{2}$ sources in southern California. This leads to a higher $\mathrm{NO}_{3}{ }^{-}$to $\mathrm{SO}_{4}{ }^{-2}$ ratio in particles, which raises the $\mathrm{pH}$. The higher $\mathrm{pH}$ then creates a positive feedback which forms more $\mathrm{NO}_{3}{ }^{-}$. Although Guo et al. (2017) focused on particles, it is possible that similar chemistry is occurring at the ground as well. Our results show that $\mathrm{HNO}_{3}$ photolysis should be considered as an important HONO source in certain urban areas and may be especially important in regions with low precipitation and high $\mathrm{NO}_{x}$ emissions.

\subsection{Source sensitivity to uptake coefficient and photolysis rate}

We performed sensitivity tests to better understand how the daytime HONO surface source is impacted by uncertainties in the mechanisms. The goal for these tests was to determine if the balance between the two major daytime mechanisms, the photo-enhanced conversion of $\mathrm{NO}_{2}$ and the photolysis of surface $\mathrm{HNO}_{3}$, could be adjusted and still provide a sufficient HONO source to match observations. We focused on uncertainties in the maximum reactive uptake coefficient $\left(\gamma_{\mathrm{NO}_{2}, \max }\right)$ and the photolysis rate enhance-

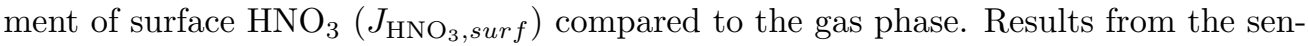


sitivity tests (Figure 9) are compared to the Base model run and a description of the changes made for each test are included in Table 2.

- Sens1 - To address the impact of uncertainties in $\gamma_{\mathrm{NO}_{2}, \text { max }}$, its value was reduced by $50 \%$ in Sens1. A corresponding increase in $J_{\mathrm{HNO}_{3}, \text { surf }}$ by $25 \%$ was then needed to maintain a surface source similar to the Base run. The noontime surface source increased from $1.6 \times 10^{11}$ in the Base run to $1.9 \times 10^{11}$ molecules $\mathrm{cm}^{-2} \mathrm{~s}^{-1}$ in Sens1. The contribution of photo-enhanced $\mathrm{NO}_{2}$ conversion at noon decreased from $32 \%$ of the total source in the Base run to $26 \%$. The contribution from surface $\mathrm{HNO}_{3}$ photolysis increased from $60 \%$ in the Base to $65 \%$.

- Sens2 - Doubling $\gamma_{\mathrm{NO}_{2}, \text { max }}$ required reducing $J_{\mathrm{HNO}_{3}, \text { surf }}$ by $20 \%$ to maintain a surface source consistent with the Base run. This run again led to good agreement with the Base run, with the total source decreasing slightly to $1.5 \times 10^{11}$ molecules $\mathrm{cm}^{-2} \mathrm{~s}^{-1}$. The contribution of photo-enhanced $\mathrm{NO}_{2}$ conversion at noon increased to $39 \%$ and the contribution from surface $\mathrm{HNO}_{3}$ photolysis decreased slightly to $58 \%$.

- Sens3 - Reducing $\gamma_{\mathrm{NO}_{2} \text {, max }}$ by $90 \%$ and increasing $J_{\mathrm{HNO}_{3}, \text { surf }}$ by $60 \%$ caused the $3 \mathrm{~m}$ HONO concentration and the total HONO source to become slightly higher.

The concentration is still within the margin of error of the HONO CIMS measurements.

- Sens4 - To test if the photo-enhanced $\mathrm{NO}_{2}$ conversion could contribute the majority of the ground $\mathrm{HONO}$ source, $\gamma_{\mathrm{NO}_{2}, \max }$ was increased by a factor of 5 and $J_{\mathrm{HNO}_{3}, \text { surf }}$ was set equal to $J_{\mathrm{HNO}_{3}, g}$. This test clearly failed to produce a strong enough source to describe HONO concentrations at $3 \mathrm{~m}$. It is evident therefore that surface $\mathrm{HNO}_{3}$ photolysis is an essential contributor to the HONO source and that it needs to proceed at a faster rate than gas phase $\mathrm{HNO}_{3}$ photolysis. It is also interesting that the photo-enhanced $\mathrm{NO}_{2}$ source is lower here than in Sens2 at most times throughout the day. Increasing $\gamma_{\mathrm{NO}_{2} \text {,max }}$ between the Base run and Sens2 caused an increase in the source due to greater $\mathrm{NO}_{2}$ uptake and conversion but this trend obviously does not continue as $\gamma_{\mathrm{NO}_{2}, \max }$ is increased more. The $\mathrm{NO}_{2}$ concentration in the lowest model layer in Sens4 is less than half the concentration in Sens2, indicating that the mechanism becomes transport limited. Although $\mathrm{NO}_{2}$ is converted at a greater rate, this is depleting $\mathrm{NO}_{2}$ near the surface that can- 


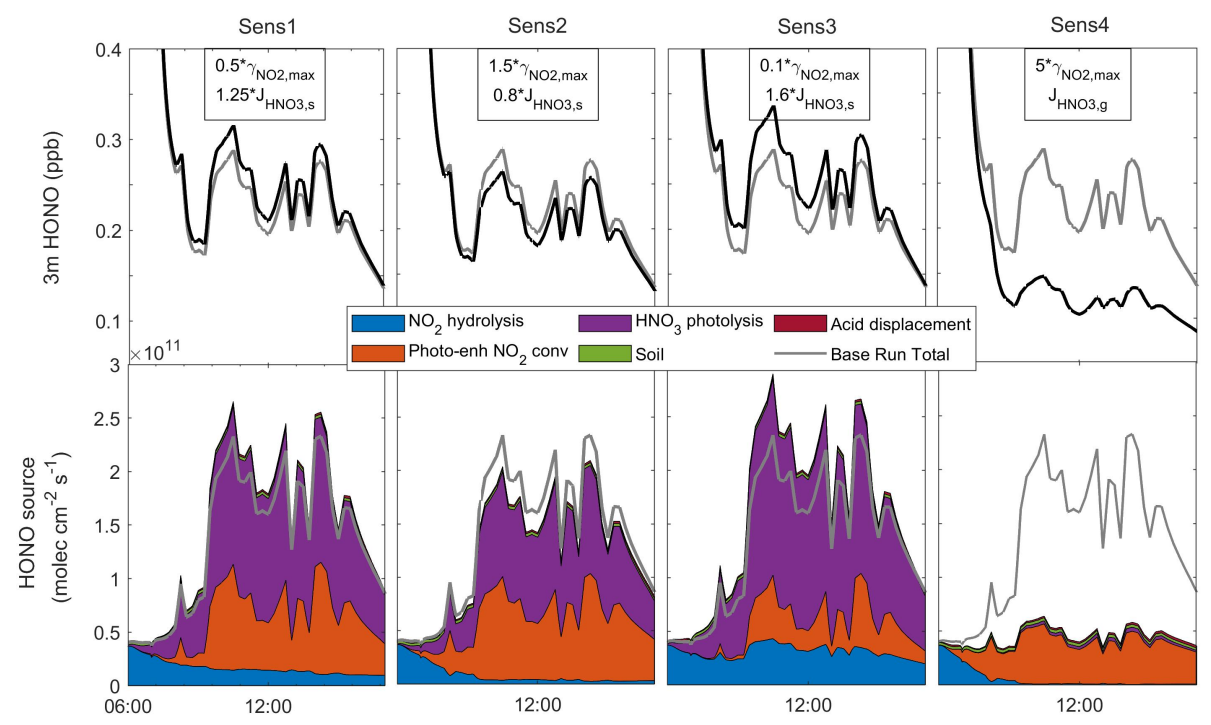

Figure 9. Results from sensitivity studies, showing $3 \mathrm{~m}$ HONO (top, black line) and the HONO ground source (bottom) for the afternoon of May 28. The Base run is shown in gray.

not be replenished quickly enough from aloft, leading to an overall decrease in HONO production.

Since both photolytic mechanisms have similar dependencies, including irradiance and $\mathrm{NO}_{x}$ concentrations, it can be difficult to determine which is more important for HONO production. These sensitivity tests show that the contributions from each mechanism are uncertain due to poorly constrained $\gamma_{\mathrm{NO}_{2} \text {, max }}$ and $J_{\mathrm{HNO}_{3}, \text { surf }}$. While it is possible for surface $\mathrm{HNO}_{3}$ photolysis to explain most of the $\mathrm{HONO}$ source, $\mathrm{NO}_{2}$ conversion alone cannot produce enough HONO in our case. Without additional laboratory studies that demonstrate the specific importance of each of these two mechanisms, it is clear that both can be considered important HONO sources in urban regions.

\section{Conclusion}

HONO's impact on secondary pollutant formation makes it an important species in urban environments. Since it's heterogeneous formation mechanisms are poorly understood, we have developed a new one-dimensional chemistry and transport model, PACT- 
1D, to perform mechanistic studies that can help constrain the HONO budget. In particular, PACT-1D has the ability to do molecular level surface chemistry and emissions. The model has been tested against observations from the CalNex field campaign, which was performed in the urban region of Los Angeles. Multiple heterogeneous source mechanisms at the ground were added to the model which helped better simulate atmospheric HONO levels, both at the ground and throughout the boundary layer. We determined that the daytime $\mathrm{HONO}$ source was dominated by $\mathrm{HNO}_{3} /$ nitrate photolysis at the ground, followed by photo-enhanced conversion of $\mathrm{NO}_{2}$. At night, the major HONO source was conversion of $\mathrm{NO}_{2}$ on the ground. With these sources implemented we determined that HONO photolysis is the dominant contributor to primary $\mathrm{OH}$ production near the surface. This contribution decreases quickly with altitude, showing a similar vertical profile to HONO concentrations. These results emphasize the importance of atmospheric mixing when considering HONO's total impact to the boundary layer and help better understand the HONO sources in urban environments. Tests were also performed to determine the sensitivity of the two major daytime HONO sources to uncertainties in their mechanisms. While their relative contributions vary with the uncertainties, it's clear that both $\mathrm{HNO}_{3} /$ nitrate photolysis and photo-enhanced conversion of $\mathrm{NO}_{2}$ should be considered to simulate HONO in urban atmospheres.

\section{Acknowledgments}

This work was supported by the National Oceanic Atmospheric Administration's Atmospheric Chemistry, Climate and Carbon Cycle program. The authors acknowledge Amélie Klein and François Ravetta for their contributions to the PACT-1D model and Jessica Gilman for the VOC measurements used in the analysis. We would also like to thank Steve Brown (NOAA) for his valuable insights.

The PACT-1D model code used in this study is available at http://doi.org/10.5281/zenodo.4776419. Output files for the base run used in this study are available at: https://doi.org/10.5281/zenodo.4776977. The CALNEX data set is available at https://www.esrl.noaa.gov/csd/projects/calnex/. 


\section{References}

Acker, K., Febo, A., Trick, S., Perrino, C., Bruno, P., Wiesen, P., ... Allegrini, I. (2006). Nitrous acid in the urban area of Rome. Atmospheric Environment, 40(17), 3123-3133. doi: 10.1016/j.atmosenv.2006.01.028

Alicke, B., Geyer, A., Hofzumhaus, A., Holland, F., Konrad, S., Patz, H., ... Platt, U. (2003). OH formation by HONO photolysis during the BERLIOZ experiment. Journal of Geophysical Research, 108(D4), 8247. doi: 10.1029/2001JD000579

Alicke, B., Platt, U., \& Stutz, J. $\quad$ (2002). Impact of nitrous acid photolysis on the total hydroxyl radical budget during the Limitation of Oxidant Production/Pianura Padana Produzione di Ozono study in Milan. Journal of Geophysical Research, 107(D22), 8196. doi: 10.1029/2000JD000075

Ammann, M., Kalberer, M., Jost, D., Tobler, L., Rössler, E., Piguet, D., .. . Baltensperger, U. (1998). Heterogeneous production of nitrous acid on soot in polluted air masses. Nature, 395(6698), 157-160. doi: 10.1038/25965

Aubin, D. G., \& Abbatt, J. P. D. (2007). Interaction of $\mathrm{NO}_{2}$ with hydrocarbon soot: Focus on HONO yield, surface modification, and mechanism. Journal of Physical Chemistry. A, $111(28), 6263-6273$. doi: 10.1021/jp068884h

Baergen, A. M., \& Donaldson, D. J. (2013). Photochemical Renoxi fi cation of Nitric Acid on Real Urban Grime. Environmental Science 83 Technology, 47 , 815-820. doi: 10.1021/es3037862

Baergen, A. M., \& Donaldson, D. J. (2016). Formation of reactive nitrogen oxides from urban grime photochemistry. Atmospheric Chemistry and Physics, 16, 6355-6363. doi: 10.5194/acp-16-6355-2016

Bartels-Rausch, T., Brigante, M., Elshorbany, Y. F., Ammann, M., D’Anna, B., George, C., ... Kleffmann, J. (2010). Humic acid in ice: Photo-enhanced conversion of nitrogen dioxide into nitrous acid. Atmospheric Environment, 25(40), 5443-5450. doi: 10.1016/j.atmosenv.2009.12.025

Borbon, A., Gilman, J. B., Kuster, W. C., Grand, N., Chevaillier, S., Colomb, A., ... De Gouw, J. A. (2013). Emission ratios of anthropogenic volatile organic compounds in northern mid-latitude megacities: Observations versus emission inventories in Los Angeles and Paris. Journal of Geophysical Research Atmospheres, 118(4), 2041-2057. doi: 10.1002/jgrd.50059 
Boy, M., Sogachev, A., Lauros, J., Zhou, L., Guenther, A., \& Smolander, S. (2011). SOSA - A new model to simulate the concentrations of organic vapours and sulphuric acid inside the ABL - Part 1: Model description and initial evaluation. Atmospheric Chemistry and Physics, 11(1), 43-51. doi: 10.5194/acp-11-43-2011

Brasseur, G. P., \& Jacob, D. J. (2017). Modeling of atmospheric chemistry. Cambridge University Press. doi: 10.1017/9781316544754

Brigante, M., Cazoir, D., D’Anna, B., George, C., \& Donaldson, D. J.

(2008). Photoenhanced uptake of $\mathrm{NO}_{2}$ by pyrene solid films.

Journal of Physical Chemistry. A, 112(39), 9503-9508. doi: 10.1021/jp802324g

Cao, L., Platt, U., \& Gutheil, E. (2016). Role of the Boundary Layer in the Occurrence and Termination of the Tropospheric Ozone Depletion Events in Polar Spring. Atmospheric Environment, 132, 98-110. doi: 10.1016/j.atmosenv.2016.02.034

Cao, L., Sihler, H., Platt, U., \& Gutheil, E. (2014). Numerical analysis of the chemical kinetic mechanisms of ozone depletion and halogen release in the polar troposphere. Atmospheric Chemistry and Physics, 14(7), 3771-3787. doi: 10.5194/acp-14-3771-2014

Czader, B. H., Rappenglück, B., Percell, P., Byun, D. W., Ngan, F., \& Kim, S. (2012). Modeling nitrous acid and its impact on ozone and hydroxyl radical during the Texas Air Quality Study 2006. Atmospheric Chemistry and Physics, 12(15), 6939-6951. doi: 10.5194/acp-12-6939-2012

Dusanter, S., Vimal, D., Stevens, P. S., Volkamer, R., \& Molina, L. T.

(2009) Measurements of $\mathrm{OH}$ and $\mathrm{HO} 2$ concentrations during the MCMA-2006 field campaign - Part 1: deployment of the indiana university laser-induced fluorescence instrument. Atmospheric Chemistry and Physics, 9(5), 1665-1685. doi: 10.5194/acp-9-1665-2009

Elshorbany, Y. F., Kurtenbach, R., Wiesen, P., Lissi, E., Rubio, M., Villena, G., ... Kleffmann, J. (2009). Oxidation capacity of the city air of Santiago, Chile. Atmospheric Chemistry and Physics, 9(3), 2257-2273. doi: 10.5194/acp-9-2257-2009

Elshorbany, Y. F., Steil, B., Brühl, C., \& Lelieveld, J. (2012). Impact of HONO on global atmospheric chemistry calculated with an empirical parameterization in 
the EMAC model. Atmospheric Chemistry and Physics Discussions, 12(5), 12885-12934. doi: 10.5194/acpd-12-12885-2012

Fu, X., Wang, T., Zhang, L., Li, Q., Wang, Z., Xia, M., ... Han, R. (2019). The significant contribution of HONO to secondary pollutants during a severe winter pollution event in southern China. Atmospheric Chemistry and Physics, 19(1), 1-14. doi: 10.5194/acp-19-1-2019

Fuchs, N., \& Sutugin, A. (1971). High-dispersed aerosols. In Topics in current aerosol research. Elsevier.

George, C., Strekowski, R. S., Kleffmann, J., Stemmler, K., \& Ammann, M. (2005). Photoenhanced uptake of gaseous $\mathrm{NO}_{2}$ on solid organic compounds: A photochemical source of HONO? Faraday Discussions, 130(2), 195-210. doi: $10.1039 / \mathrm{b} 417888 \mathrm{~m}$

Geyer, A., \& Stutz, J. (2004a). Vertical profiles of NO3, N2O5, O3, and NOx in the nocturnal boundary layer: 2. Model studies on the altitude dependence of composition and chemistry. Journal of Geophysical Research, 109(D12), 1-18. doi: 10.1029/2003JD004211

Geyer, A., \& Stutz, J. (2004b). The vertical structure of OH-HO2 -RO2 chemistry in the nocturnal boundary layer: A one-dimensional model study. Journal of Geophysical Research, 109(D16), 1-17. doi: 10.1029/2003JD004425

Gilman, J. B., Burkhart, J. F., Lerner, B. M., Williams, E. J., Kuster, W. C., Goldan, P. D., ... de Gouw, J. A. (2010). Ozone variability and halogen oxidation within the Arctic and sub-Arctic springtime boundary layer. Atmospheric Chemistry and Physics, 10(21), 10223-10236. doi: 10.5194/acp-10-10223-2010

Goliff, W. S., Stockwell, W. R., \& Lawson, C. V. (2013). The Regional Atmospheric Chemistry Mechanism, Version 2. Atmospheric Environment, 68, 174-185. doi: 10.1016/j.atmosenv.2012.11.038

Granier, C., Darras, S., Denier Van Der Gon, H., Jana, D., Elguindi, N., Bo, G., ... Kuenen, J. (2019). The Copernicus Atmosphere Monitoring Service global and regional emissions (April 2019 version). Data from ECCAD.

Griffith, S. M., Hansen, R., Dusanter, S., Michoud, V., Gilman, J., Kuster, W., ... Stevens, P. (2016). Measurements of hydroxyl and hydroperoxy radicals during CalNex-LA: Model comparisons and radical budgets. Journal of Geophysical 
Research : Atmospheres, 4211-4232. doi: 10.1002/2015JD024358

Guo, H., Liu, J., Froyd, K. D., Roberts, J. M., Veres, P. R., Hayes, P. L., ... Weber, R. J. (2017). Fine particle pH and gas-particle phase partitioning of inorganic species in Pasadena, California, during the 2010 CalNex campaign. Atmospheric Chemistry and Physics, 17(9), 5703-5719. doi: $10.5194 /$ acp-17-5703-2017

Gutzwiller, L., Arens, F., Baltensperger, U., Gaggeler, H., \& Ammann, M. (2002). Significance of semivolatile diesel exhaust organics for secondary HONO formation. Environ. Sci. Technol, 36(4), 677-682. doi: 10.1021/es015673b

Hayes, P. L., Ortega, A. M., Cubison, M. J., Froyd, K. D., Zhao, Y., Cliff, S. S., ... Jimenez, J. L. (2013). Organic aerosol composition and sources in Pasadena, California, during the 2010 CalNex campaign. Journal of Geophysical Research Atmospheres, 118(16), 9233-9257. doi: 10.1002/jgrd.50530

Jenkin, M., Cox, R., \& Williams, D. (1988). Laboratory studies of the kinetics of formation of nitrous acid from the thermal reaction of nitrogen dioxide and water vapour. $\quad$ Atmospheric Environment, 22(3), 487-498. doi: 10.1016/0004-6981(88)90194-1

Kalberer, M., Ammann, M., Arens, F., G, H. W., \& Baltensperger, U. (1999). Heterogeneous formation of nitrous acid (HONO) on soot aerosol particles. , 104, $13825-13832$

Karamchandani, P., Emery, C., Yarwood, G., Lefer, B., Stutz, J., Couzo, E., \& Vizuete, W. (2014). Implementation and refinement of a surface model for heterogeneous HONO formation in a 3-D chemical transport model. Atmospheric Environment, 112, 356-368. doi: 10.1016/j.atmosenv.2015.01.046

Khalizov, A. F., Cruz-Quinones, M., \& Zhang, R. (2010). Heterogeneous reaction of $\mathrm{NO}_{2}$ on fresh and coated soot surfaces. Journal of Physical Chemistry A, 114(28), 7516-7524. doi: 10.1021/jp1021938

Kim, S., Mcdonald, B. C., Baidar, S., Brown, S. S., Dube, B., Ferrare, R. A., ... Young, C. J. (2016). Modeling the weekly cycle of NOx and CO emissions and their impacts on O3 in the Los Angeles-South Coast Air Basin during the CalNex 2010 field campaign. Journal of Geophysical Research : Atmospheres, 1340-1360. doi: 10.1002/2015JD024292

Kirchstetter, T. W., Harley, R. A., \& Littlejohn, D. (1996). Measurement of ni- 
trous acid in motor vehicle exhaust. Environmental Science and Technology, 30, 2843-2849. doi: 10.1021/es960135y

Kleffmann, J. (2007). Daytime sources of nitrous acid (HONO) in the atmospheric boundary layer. ChemPhysChem, 8(8), 1137-1144. doi: 10.1002/cphc. 200700016

Kleffmann, J., Gavriloaiei, T., Hofzumahaus, A., Holland, F., Koppmann, R., Rupp, L., ... Wahner, A. (2005). Daytime formation of nitrous acid: A major source of $\mathrm{OH}$ radicals in a forest. Geophysical Research Letters, 32, L05818. doi: 10.1029/2005GL022524

Kleffmann, J., Kurtenbach, R., Lörzer, J., Wiesen, P., Kalthoff, N., Vogel, B., \& Vogel, H. (2003). Measured and simulated vertical profiles of nitrous acid - Part I: Field measurements. Atmospheric Environment, 37(21), 2949-2955. doi: 10.1016/S1352-2310(03)00242-5

Kleffmann, J., Lörzer, J. C., Wiesen, P., Kern, C., Trick, S., Volkamer, R., ... Wirtz, K. (2006). Intercomparison of the DOAS and LOPAP techniques for the detection of nitrous acid (HONO). Atmospheric Environment, 40(20), 3640-3652. doi: 10.1016/j.atmosenv.2006.03.027

Kramer, L., Crilley, L., Adams, T., Ball, S., Pope, F., \& Bloss, W. (2019). $\quad$ Nitrous acid (HONO) emissions under real-world driving conditions from vehicles in a UK road tunnel. Atmospheric Chemistry and Physics(2), 1-31. doi: 10.5194/acp-2019-1070

Kurtenbach, R., Becker, K. H., Gomes, J. A. G., Kleffmann, J., Lorzer, J., Spittler, M., ... Platt, U. (2001). Investigations of emissions and heterogeneous formation of HONO in a road traffic tunnel. Atmospheric Environment, 35, 3385-3394. doi: 10.1016/S1352-2310(01)00138-8

Lammel, G., \& Cape, J. (1996). Nitrous acid and nitrite in the atmosphere. Chem. Soc. Rev., 25, 361-369. doi: 10.1039/CS9962500361

Laufs, S., Cazaunau, M., Stella, P., Kurtenbach, R., Cellier, P., Mellouki, A., ... Kleffmann, J. (2017). Diurnal fluxes of HONO above a crop rotation. Atmospheric Chemistry and Physics, 17(11), 6907-6923. doi: 10.5194/acp-17-6907-2017

Li, Y., An, J., Min, M., Zhang, W., Wang, F., \& Xie, P. (2011). Impacts of HONO sources on the air quality in Beijing, Tianjin and Hebei Province of China. At- 
mospheric Environment, 45(27), 4735-4744. doi: 10.1016/j.atmosenv.2011.04 .086

Liu, J., Liu, Z., Ma, Z., Yang, S., Yao, D., Zhao, S., .. Wang, Y. (2021). Detailed budget analysis of HONO in Beijing, China: Implication on atmosphere oxidation capacity in polluted megacity. Atmospheric Environment, 244(April 2020). doi: $10.1016 /$ j.atmosenv.2020.117957

Maljanen, M., Yli-Pirilä, P., Hytönen, J., Joutsensaari, J., \& Martikainen, P. J.

Acidic northern soils as sources of atmospheric nitrous acid (HONO). Soil Biology and Biochemistry, 67(2), 94-97. doi: 10.1016/ j.soilbio.2013.08.013

Mao, J., Ren, X., Chen, S., Brune, W. H., Chen, Z., Martinez, M., ... Leuchner, M. (2010). Atmospheric oxidation capacity in the summer of Houston 2006: Comparison with summer measurements in other metropolitan studies. Atmospheric Environment, 44 (33), 4107-4115. doi: 10.1016/ j.atmosenv.2009.01.013

Meusel, H., Tamm, A., Kuhn, U., Wu, D., Lena Leifke, A., Fiedler, S., .. Cheng, Y. (2018). Emission of nitrous acid from soil and biological soil crusts represents an important source of $\mathrm{HONO}$ in the remote atmosphere in Cyprus. Atmospheric Chemistry and Physics, 18(2), 799-813. doi: 10.5194/acp-18-799-2018

Monge, M. E., D'Anna, B., \& George, C. (2010). Nitrogen dioxide removal and nitrous acid formation on titanium oxide surfaces - an air quality remediation process? Physical Chemistry Chemical Physics, 12(31), 8991-8998. doi: $10.1039 / \mathrm{b} 925785 \mathrm{c}$

Neuman, J. A., Ryerson, T. B., Huey, L. G., Jakoubek, R., Nowak, J. B., Simons, C., \& Fehsenfeld, F. C. (2003). Calibration and evaluation of nitric acid and ammonia permeation tubes by UV optical absorption. Environmental Science and Technology, 37(13), 2975-2981. doi: 10.1021/es0264221

Neuman, J. A., Trainer, M., Brown, S. S., Min, K.-E., Nowak, J. B., Parrish, D. D., ... Veres, P. R. (2016). HONO emission and production determined from airborne measurements over the Southeast U.S. Journal of Geophysical Research, 121(15), 9237-9250. doi: 10.1002/2016JD025197

Oswald, R., Behrendt, T., Ermel, M., Wu, D., Su, H., Cheng, Y., ... Trebs, I. (2013) HONO emissions from soil bacteria as a major source of atmo- 
spheric reactive nitrogen. Science, 341(6151), 1233-1235. doi: 10.1126/ science. 1242266

Pitts, J., Sanhueza, E., Atkinson, R., Carter, W., Winer, A., Harris, G. W., \& Plum, C. (1984). An investigation of the dark formation of nitrous acid in environmental chambers. International Journal of Chemical Kinetics, 16, 919-939. doi: $10.1002 /$ kin. 550160712

Platt, U., \& Stutz, J. (2008). Differential Optical Absorption Spectroscopy. Berlin, Heidelberg: Springer Berlin Heidelberg. doi: 10.1007/978-3-540-75776-4

Pollack, I. B., Lerner, B. M., \& Ryerson, T. B. ～(2010). Evaluation of ultraviolet light-emitting diodes for detection of atmospheric NO2 by photolysis - Chemiluminescence. Journal of Atmospheric Chemistry, 65(2-3), 111-125. doi: 10.1007/s10874-011-9184-3

Pusede, S. E., VandenBoer, T. C., Murphy, J. G., Markovic, M. Z., Young, C. J., Veres, P. R., ... Cohen, R. C. (2015). An Atmospheric Constraint on the NO 2 Dependence of Daytime Near-Surface Nitrous Acid (HONO). Environmental Science and Technology, 49(21), 12774-12781. doi: 10.1021/acs.est.5b02511

Ramazan, K. A., Syomin, D., \& Finlayson-Pitts, B. J. (2004). The photochemical production of HONO during the heterogeneous hydrolysis of NO2. Physical Chemistry Chemical Physics, 6(14), 3836-3843. doi: 10.1039/b402195a

Ren, X., Harder, H., Martinez, M., \& Lesher, R. (2003). HOx concentrations and OH reactivity observations in New York City during PMTACS-NY2001. Atmospheric Environment, 37(26), 3627-3637. doi: 10.1016/S1352-2310(03)00460 $-6$

Ren, X., Sanders, J. E., Rajendran, A., Weber, R. J., Goldstein, A. H., Pusede, S. E., ... Cohen, R. C. (2011). A relaxed eddy accumulation system for measuring vertical fluxes of nitrous acid. Atmospheric Measurement Techniques, 4 (10), 2093-2103. doi: 10.5194/amt-4-2093-2011

Roberts, J. M., Veres, P., Warneke, C., Neuman, J. A., Washenfelder, R. A., Brown, S. S., ... de Gouw, J. (2010). Measurement of HONO, HNCO, and other inorganic acids by negative-ion proton-transfer chemical-ionization mass spectrometry (NI-PT-CIMS): application to biomass burning emissions. Atmospheric Measurement Techniques, 3(4), 981-990. doi: 10.5194/amt-3-981-2010

Ryerson, T. B., Andrews, A. E., Angevine, W. M., Bates, T. S., Brock, C. A., 
Cairns, B., ... Wofsy, S. C. (2013). The 2010 California Research at the Nexus of Air Quality and Climate Change (CalNex) field study. Journal of Geophysical Research: Atmospheres, 118(11), 5830-5866. doi: 10.1002/jgrd.50331

Sakamaki, F., Hatakeyama, S., \& Akimoto, H. (1983). Formation of nitrous acid and nitric oxide in the heterogeneous dark reaction of nitrogen dioxide and water vapor in a smog chamber. International Journal of Chemical Kinetics, 15, 1013-1029. doi: 10.1002/kin.550151006

Sandu, A., \& Sander, R. (2006). Technical Note: Simulating Chemical Systems in Fortran90 and Matlab with the Kinetic PreProcessor KPP-2.1. Atmospheric Chemistry and Physics, 6(1), 187-195. doi: https://doi.org/10.5194/acp-6-187 $-2006$

Sarwar, G., Roselle, S. J., Mathur, R., Appel, W., Dennis, R. L., \& Vogel, B. (2008). A comparison of CMAQ HONO predictions with observations from the Northeast Oxidant and Particle Study. Atmospheric Environment, 42(23), 57605770. doi: 10.1016/j.atmosenv.2007.12.065

Scharko, N. K., Schütte, U. M. E., Berke, A. E., Banina, L., Peel, H. R., Donaldson, M. a., ... Raff, J. D. (2015). Combined flux chamber and genomics approach links nitrous acid emissions to ammonia oxidizing bacteria and archaea in urban and agricultural soil. Environmental Science $\mathcal{G}$ Technology, 49(23), 13825-13834. doi: 10.1021/acs.est.5b00838

Shetter, R. E., \& Müller, M. (1999). Photolysis frequency measurements using actinic flux spectroradiometry during the PEM-Tropics mission: Instrumentation description and some results. Journal of Geophysical Research: Atmospheres, 104(D5), 5647-5661. doi: 10.1029/98JD01381

Simpson, D., Andersson, C., Christensen, J. H., Engardt, M., Geels, C., Nyiri, A., ... Langner, J. (2014). Impacts of climate and emission changes on nitrogen deposition in Europe: A multi-model study. Atmospheric Chemistry and Physics, 14 (13), 6995-7017. doi: 10.5194/acp-14-6995-2014

Stemmler, K., Ammann, M., Donders, C., Kleffmann, J., \& George, C. (2006). Photosensitized reduction of nitrogen dioxide on humic acid as a source of nitrous acid. Nature, 440(7081), 195-198. doi: 10.1038/nature04603

Stemmler, K., Ndour, M., Elshorbany, Y., Kleffmann, J., D'Anna, B., George, C., ... Ammann, M. (2007). Light induced conversion of nitrogen dioxide into nitrous 
acid on submicron humic acid aerosol. Atmospheric Chemistry and Physics, 7(16), 4237-4248. doi: 10.5194/acp-7-4237-2007

Stutz, J., Wong, K. W., Lawrence, L., Ziemba, L., Flynn, J. H., Rappenglück, B., \& Lefer, B. (2010). Nocturnal NO3 Radical Chemistry in Houston, TX. Atmospheric Environment, 44(33), 4099-4106. doi: 10.1016/ j.atmosenv.2009.03.004

Su, H., Cheng, Y., Oswald, R., Behrendt, T., Trebs, I., Meixner, F. X., .. Pöschl, U. (2011). Soil nitrite as a source of atmospheric HONO and OH radicals. Science, 333(6049), 1616-1618. doi: 10.1126/science.1207687

Svensson, R., Ljungström, E., \& Lindqvist, O. (1987). Kinetics of the reaction between nitrogen dioxide and water vapour. Atmospheric Environment, 21(7), 1529-1539. doi: 10.1016/0004-6981(87)90315-5

Thomas, J. L., Dibb, J. E., Huey, L. G., Liao, J., Tanner, D., Lefer, B., ... Stutz, J. (2012). Modeling chemistry in and above snow at Summit, Greenland Part 2: Impact of snowpack chemistry on the oxidation capacity of the boundary layer. Atmospheric Chemistry and Physics, 12(14), 6537-6554. doi: 10.5194/acp-12-6537-2012

Thomas, J. L., Stutz, J., Lefer, B., Huey, L. G., Toyota, K., Dibb, J. E., \& von Glasow, R. (2011). Modeling chemistry in and above snow at Summit, Greenland - Part 1: Model description and results. Atmospheric Chemistry and Physics, 11(10), 4899-4914. doi: 10.5194/acp-11-4899-2011

Toyota, K., Dastoor, A. P., \& Ryzhkov, A. $\quad$ (2014). Air-snowpack exchange of bromine, ozone and mercury in the springtime Arctic simulated by the 1-D model PHANTAS - Part 2: Mercury and its speciation. Atmospheric Chemistry and Physics, 14 (8), 4135-4167. doi: 10.5194/acp-14-4135-2014

Trick, S. (2004). Formation of Nitrous Acid on Urban Surfaces - a physical chemical perspective (Unpublished doctoral dissertation).

Tsai, C., Spolaor, M., Fedele Colosimo, S., Pikelnaya, O., Cheung, R., Williams, E., ... Stutz, J. (2018). Nitrous acid formation in a snow-free wintertime polluted rural area. Atmospheric Chemistry and Physics, 18(3), 1977-1996. doi: 10.5194/acp-18-1977-2018

Tsai, C., Wong, C., Hurlock, S., Pikelnaya, O., Mielke, L. H., Osthoff, H. D., ... Stutz, J. (2014). Nocturnal loss of NOx during the 2010 CalNex-LA study 
in the Los Angeles Basin. Journal of Geophysical Research, 119(22), 1300413025. doi: 10.1002/2014JD022171

VandenBoer, T. C., Brown, S. S., Murphy, J. G., Keene, W. C., Young, C. J., Pszenny, A. A. P., .. Roberts, J. M. (2013). Understanding the role of the ground surface in $\mathrm{HONO}$ vertical structure: High resolution vertical profiles during NACHTT-11. Journal of Geophysical Research: Atmospheres, 118, 10155-10171. doi: 10.1002/jgrd.50721

VandenBoer, T. C., Young, C. J., Talukdar, R. K., Markovic, M. Z., Brown, S. S., Roberts, J. M., \& Murphy, J. G. (2015). Nocturnal loss and daytime source of nitrous acid through reactive uptake and displacement. Nature Geoscience, 8(1), 55-60. doi: 10.1038/ngeo2298

Veres, P. R., Roberts, J. M., Cochran, A. K., Gilman, J. B., Kuster, W. C., Holloway, J. S., . . De Gouw, J. (2011). Evidence of rapid production of organic acids in an urban air mass. Geophysical Research Letters, 38(17), 1-5. doi: 10.1029/2011GL048420

Veres, P. R., Roberts, J. M., Warneke, C., Welsh-Bon, D., Zahniser, M., Herndon, S., ... de Gouw, J. (2008). Development of negative-ion proton-transfer chemical-ionization mass spectrometry (NI-PT-CIMS) for the measurement of gas-phase organic acids in the atmosphere. International Journal of Mass Spectrometry, 274(1-3), 48-55. doi: 10.1016/j.ijms.2008.04.032

Villena, G., Wiesen, P., Cantrell, C. A., Flocke, F., Fried, A., Hall, S. R., ... Kleffmann, J. (2011). Nitrous acid (HONO) during polar spring in Barrow, Alaska: A net source of OH radicals? Journal of Geophysical Research, 116, D00R07. doi: $10.1029 / 2011 J D 016643$

Vogel, B., Vogel, H., Kleffmann, J., \& Kurtenbach, R. ～(2003). Measured and simulated vertical profiles of nitrous acid - Part II. Model simulations and indications for a photolytic source. Atmospheric Environment, 37(21), 2957-2966. doi: 10.1016/S1352-2310(03)00243-7

Volkamer, R., Sheehy, P., Molina, L. T., \& Molina, M. J. (2010). Oxidative capacity of the Mexico City atmosphere - Part 1: A radical source perspective. Atmospheric Chemistry and Physics, 10(14), 6969-6991. doi: 10.5194/acp-10-6969 $-2010$

von Glasow, R., Sander, R., Bott, A., \& Crutzen, P. J. (2002a). Modeling halogen 
chemistry in the marine boundary layer 1. Cloud-free MBL. Journal of Geophysical Research, 107(D17), 4341. doi: 10.1029/2001JD000942

von Glasow, R., Sander, R., Bott, A., \& Crutzen, P. P. J. (2002b). Modeling halogen chemistry in the marine boundary layer 2 . Interactions with sulfur and the cloud-covered MBL. Journal of Geophysical Research, 107(D17), 4323. doi: 10.1029/2001JD000943

Wang, S., McNamara, S. M., Kolesar, K. R., May, N. W., Fuentes, J. D., Cook, R. D., ... Pratt, K. A. (2020). Urban Snowpack ClNO2 Production and Fate: A One-Dimensional Modeling Study. ACS Earth and Space Chemistry, 4(7), 1140-1148. doi: 10.1021/acsearthspacechem.0c00116

Washenfelder, R. A., Wagner, N. L., Dube, W. P., \& Brown, S. S. (2011). Measurement of atmospheric ozone by cavity ring-down spectroscopy. Environmental Science and Technology, 45(7), 2938-2944. doi: 10.1021/es103340u

Wolfe, G. M., Marvin, M. R., Roberts, S. J., Travis, K. R., \& Liao, J. (2016). The framework for 0-D atmospheric modeling (F0AM) v3.1. Geoscientific Model Development, 9(9), 3309-3319. doi: 10.5194/gmd-9-3309-2016

Wong, K., Oh, H.-J., Lefer, B. L., Rappenglück, B., \& Stutz, J. (2011). Vertical profiles of nitrous acid in the nocturnal urban atmosphere of Houston, TX. Atmospheric Chemistry and Physics, 11(8), 3595-3609. doi: 10.5194/acp-11-3595 $-2011$

Wong, K., Tsai, C., Lefer, B., Grossberg, N., \& Stutz, J. (2013). Modeling of daytime HONO vertical gradients during SHARP 2009. Atmospheric Chemistry and Physics, 13(7), 3587-3601. doi: 10.5194/acp-13-3587-2013

Wong, K., Tsai, C., Lefer, B., Haman, C., Grossberg, N., Brune, W., ... Stutz, J. (2012). Daytime HONO vertical gradients during SHARP 2009 in Houston, TX. Atmospheric Chemistry and Physics, 12(2). doi: 10.5194/ acp-12-635-2012

Ye, C., Gao, H., Zhang, N., \& Zhou, X. (2016). Photolysis of nitric acid and nitrate on natural and artificial surfaces. Environmental Science and Technology, 50(7), 3530-3536. doi: 10.1021/acs.est.5b05032

Ye, C., Zhang, N., Gao, H., \& Zhou, X. (2019). Matrix effect on surface-catalyzed photolysis of nitric acid. Scientific Reports(October 2018), 1-10. doi: 10.1038/ s41598-018-37973-x 
Young, C. J., Washenfelder, R. A., Roberts, J. M., Mielke, L. H., Osthoff, H. D., Tsai, C., ... Brown, S. S. (2012). Vertically resolved measurements of nighttime radical reservoirs in Los Angeles and their contribution to the urban radical budget. Environmental Science \& Technology, 46(20), 10965-10973. doi: $10.1021 /$ es302206a

Zhang, N., Zhou, X., Bertman, S., Tang, D., Alaghmand, M., Shepson, P. B., \& Carroll, M. a. (2012). Measurements of ambient HONO concentrations and vertical HONO flux above a northern Michigan forest canopy. Atmospheric Chemistry and Physics Discussions, 12(3), 7273-7304. doi: 10.5194/acpd-12-7273-2012

Zhang, N., Zhou, X., Shepson, P. B., Gao, H., Alaghmand, M., \& Stirm, B. (2009). Aircraft measurement of HONO vertical profiles over a forested region. Geophysical Research Letters, 36(15), L15820. doi: 10.1029/2009GL038999

Zheng, W., Flocke, F. M., Tyndall, G. S., Swanson, A., Orlando, J. J., Roberts, J. M., ... Tanner, D. J. (2011). Characterization of a thermal decomposition chemical ionization mass spectrometer for the measurement of peroxy acyl nitrates (PANs) in the atmosphere. Atmospheric Chemistry and Physics, 11(13), 6529-6547. doi: 10.5194/acp-11-6529-2011

Zhou, X., Civerolo, K., Dai, H., Huang, G., Schwab, J., \& Demerjian, K. $(2002)$ Summertime nitrous acid chemistry in the atmospheric boundary layer at a rural site in New York State. Journal of Geophysical Research, 107(D21), 4590. doi: 10.1029/2001JD001539

Zhou, X., Gao, H., He, Y., Huang, G., Bertman, S., Civerolo, K., \& Schwab, J. (2003). Nitric acid photolysis on surfaces in low-NOx environments: Significant atmospheric implications. Geophysical Research Letters, 30(23), $2217 . \quad$ doi: 10.1029/2003GL018620

Zhou, X., Huang, G., Civerolo, K., Roychowdhury, U., \& Demerjian, K. L. (2007). Summertime observations of $\mathrm{HONO}, \mathrm{HCHO}$, and $\mathrm{O}_{3}$ at the summit of Whiteface Mountain, New York. Journal of Geophysical Research, 112, D08311. doi: 10.1029/2006JD007256

Zhou, X., Zhang, N., TerAvest, M., Tang, D., Hou, J., Bertman, S., ... Stevens, P. S. (2011). Nitric acid photolysis on forest canopy surface as a source for tropospheric nitrous acid. Nature Geoscience, 4(6), 400-443. doi: 
10.1038/ngeo1164 